Anuario del Instituto de Historia Argentina, junio 2018, vol. 18, n 1, e068. ISSN 2314-257X

Universidad Nacional de La Plata

Facultad de Humanidades y Ciencias de la Educación

Centro de Historia Argentina y Americana

\title{
Publicidades de golosinas, consumo y felicidad infantil (Argentina, 1930-1943)
}

Scheinkman, Ludmila

Universidad de Buenos Aires, Instituto Internacional de Estudios de Género - CONICET, Argentina

ludsch@gmail.com

Cita sugerida: Scheinkman, L.(2018).Publicidades de golosinas, consumo y felicidad infantil (Argentina, 1930-1943) Anuario del Instituto de Historia Argentina, 18 (1), e068. https://doi.org/10.24215/2314-257Xe068

Recibido: 31 Diciembre 2017 - Aceptado: 19 Abril 2018 - Publicado: 28 de junio de 2018

(c) (1) (2) Esta obra está bajo licencia Creative Commons Atribución-NoComercial-CompartirIgual 4.0 Internacional cc) $\mathrm{http}: / /$ creativecommons.org/licenses/by-nc-sa/4.0/deed.es_AR 


\section{Publicidades de golosinas, consumo y felicidad infantil (Argentina, 1930-1943)}

\section{Candy Advertising, Consumption and Childhood Happiness (Argentina, 1930-1943)}

\section{Ludmila Scheinkman}

Universidad de Buenos Aires, Instituto Internacional de

Estudios de Género - CONICET, Argentina

ludsch@gmail.com

\section{Resumen:}

Este trabajo indaga en las imágenes publicitarias con que las industrias de dulces y golosinas difundieron, crearon, y modificaron a escala masiva roles sociales y construcciones de la infancia en Argentina en los años 30. En este análisis advertimos una mutación trascendente en los argumentos y apelaciones publicitarias que tuvieron a los niños/as como destinatarios centrales: una vinculación decisiva entre infancia y felicidad, con antecedentes pero tornándose dominante en ésta década. Felicidad que se obtendría, según los anunciantes, al consumir estos bienes que además de placer proporcionaban juegos y entretenimientos para alegrar a niños/as, y prometían una infancia feliz.

Palabras Clave: Infancia, Consumo, Publicidad.

\section{Abstract:}

This article explores advertising images produced by the candy and confectionery industries, which disseminated, created, and modified on a massive scale social roles and constructions of childhood in Argentina in the 1930s. In this analysis, we point out a significant transformation in the arguments and appeals used by publicity directed to children: the emergence of a decisive link between childhood and happiness, which became dominant in this decade. This happiness would be attained, according to the advertisers, by consuming these goods, which in addition to pleasure provided games and entertainment to cheer up children, and promised happy childhoods.

KEYworDs: Childhood, Consumption, Advertising.

"Cuando en los oídos de los padres y de los amigos, resuena todavía el grito de júbilo de los niños contentos que han obtenido algunos de los premios que la vez pasada se distribuyeron entre los niños del país, ya la voz de Saint Hnos., anuncia el segundo sorteo". Anuncio de Chocolatines Águila, El Mundo, 7/12/1933.

\section{INTRODUCCIÓN}

"Recuerdo el camino al cole con olor a chocolate. Y tampoco olvidaré las historias de mi papá que me contaba de los álbumes que al llenar le hacían ganar pelotas o bicis (porque los chocolates tenían una figurita); cada vez que pasábamos [por la fábrica de chocolates Águila] me lo contaba, me quejaba de tantas veces que la decía pero hoy las extraño como a él" ${ }^{1}$. Memorias como la de Alejandra, vecina de Buenos Aires, en que los años escolares se asocian a clásicos chocolatines, figuritas y premios, se repiten en numerosos relatos de infancia. Cargados de nostalgia, estos evocan no sólo años de juventud, sino también ciertos consumos, así como vínculos y prácticas estructuradas en torno a ellos. Estas asociaciones entre una etapa en la vida -la infancia-, romantizada en forma de recuerdos felices, y ciertos consumos y marcas, fueron compartidas por muchos de quienes vivieron su niñez y juventud desde los años 30 en Argentina, y revelan el éxito y la coronación de las estrategias publicitarias de las fábricas de dulces porteñas. Pero además, son una puerta de entrada para 
reflexionar sobre transformaciones más profundas en las condiciones y expectativas en torno a la infancia en Argentina en la década del 30.

La publicidad y la industria no son, tal vez, las puertas de entrada más frecuentes para estudiar la historia de la infancia y las familias. Sin embargo, esta investigación es deudora del campo de indagación fértil y en expansión que ha puesto a la infancia en el centro de su agenda, estudiando el papel del Estado, los saberes y las corporaciones médicas, educativas, psicológicas y jurídicas que buscaron influir sobre las familias, las mujeres-madres y la crianza de los niños (Aversa, 2006; Ciafardo, 1992; Cosse, 2006; Guy, 1998; Ríos y Talak, 2002, entre otras; algunas compilaciones recientes que reflejan este dinamismo: Carli, 2006; Cosse, Llobet, Villalta, y Zapiola, 2011; Lionetti y Míguez, 2010; Llobet, 2014; Villalta, 2010). Por otro lado, esta pesquisa se vincula también con una pujante área de estudios sobre la historia del consumo (Arcondo, 2002; Elena, 2011; Milanesio, 2014; Pérez, 2015; Pite, 2013; Remedi, 2006; 1998, 1999, 2003; Salvatore, 2005). En particular, los trabajos de Paula Bontempo sobre los niños y niñas consumidores de revistas infantiles en los años 20 y 30 se insertan en el cruce de estas tradiciones y han señalado la emergencia de la infancia como sujeto de consumo (Bontempo, 2012, 2015, 2016), así como los de Sandra Szir sobre cultura visual, consumo y publicaciones infantiles a fines del siglo XIX y comienzos del XX (Szir, 2007, 2009, 2013). Un trayecto similar advertimos en la historia de la infancia en América Latina, también en expansión y renovación, donde un creciente número de trabajos han tratado de pensar las vinculaciones históricas entre infancia, cultura visual, publicidades y mercado de consumo. Estos han señalado también que entrado el siglo XX los niños emergieron como mercado, y que el consumo -así como el ahorro- formó parte de su educación ciudadana. Diana Aristizábal García y Susana Sosenski han estudiado, para Colombia y México respectivamente, la emergencia a mediados del siglo XX de los niños como sujetos consumidores deseantes, con gustos y necesidades propias (para México: Sosenski, 2012, 2014; Sosenski y León, 2015; Colombia: Aristizábal García, 2016; Chile: Dussaillant Christie, 2016; Rojas Flores, 2005).

Este trabajo se ubica en el cruce de estas tradiciones, y tiene como objeto indagar en las imágenes publicitarias con que las industrias y el sector privado difundieron, crearon, y modificaron a escala masiva roles sociales y construcciones de la infancia, nutriéndose de los discursos ideológicos que circulaban en la sociedad con una intencionalidad comercial y una especificidad propia. Proponemos aquí que es posible advertir en los años 30 una mutación trascendente en los argumentos y formas de apelación publicitaria de los anuncios de dulces. Una ligazón fundamental entre la infancia y consumos asociados al goce y la felicidad infantil, con cierta presencia en los años 20, se tornó en esta década en el dispositivo privilegiado para vender productos que tuvieron a los niños como destinatarios centrales.

El estudio de las publicidades de dulces, chocolates y golosinas, que en los años 30 se dirigieron centralmente a los niños, nos vincula no sólo con un proceso general de expansión y segmentación del mercado de consumo y el campo publicitario en la Argentina de entreguerras (Rocchi, 2003, 2016, 2017; Salvatore, 2005; Scheinkman, 2017a), sino también con una problemática poco atendida en relación a la historia de la infancia. Esto es, en el estudio de las publicidades de dulces puede observarse cómo se produjo una vinculación decisiva entre infancia y felicidad, que reconocía antecedentes pero se hizo dominante en ésta década y persiste con modificaciones hasta nuestros días (un trabajo actual que registra dicha permanencia: Minzi, 2006). La felicidad infantil, como aparecía en los anuncios, no consistía simplemente en la ausencia de tristeza, sino en la presencia de alegría, sonrisas, disfrute y placer, producto del juego y el consumo ${ }^{2}$. Así definida, esta felicidad se obtendría, según los anunciantes, por medio del consumo de ciertos bienes, que además de generar placer proporcionaban juegos y entretenimientos que alegraban a los niños y niñas y prometían una infancia feliz.

Esto es sintomático de un cambio iniciado en los años 20, cuando los dulces, galletitas y bizcochos comenzaron a adquirir el carácter de "golosinas", de productos sabrosos y atrayentes que brindaban goce con el consumo, pero que se tornó preponderante en la década siguiente. De este modo, los anuncios publicitarios de alimentos dulces anticiparon la "renovación en las representaciones familiares" que advirtió Hugo Vezzetti 
en la década del 30 en la literatura de divulgación ligada a la salud. En esta, la anterior apelación fundada en un sistema de deberes necesarios para el buen desempeño colectivo de la nación y la raza fue cediendo lugar a una asociación de la salud y el bienestar con la "felicidad" individual, el confort y la vida como "disfrute" (Vezzetti, 1986, pp 5-7), que como veremos, se plasmó en las publicidades de dulces orientadas a los niños en los años 30, y en los avisos médicos y de alimentos para suplementar la salud en los años 40 (Traversa, 1997, pp 177, 259).

Un proceso similar observan Susana Sosenski y Ricardo López León para México desde los años 30, cuando en las publicidades hubo un encuentro discursivo entre consumo y felicidad, y una ligazón entre esta última y la infancia, sostenida en la convivencia del núcleo familiar y el disfrute de ciertos productos (Sosenski y León, 2015, p 194). Por su parte, Jorge Rojas Flores advierte cómo en Chile a partir de los años 20 el juego como actividad lúdica propia de la infancia fue cobrando centralidad, llegando incluso a considerarse en la actualidad que "un niño que no se divierte, no juega y no ríe no ha vivido la infancia" (Rojas Flores, 2005, p 349). Esto era parte de un proceso más amplio en el mundo occidental, que se masificó en los Estados Unidos en los años 20 y 30 , en el que se transformaron las expectativas y las obligaciones parentales en torno a una infancia que ahora debía tener entre sus objetivos centrales la felicidad (Stearns, 2010, pp 167, 172). La difusión del consumismo tuvo un papel de gran importancia en este proceso, en tanto la adquisición de bienes que proveyeran felicidad a niñas y niños fue una vía, promovida por los esfuerzos publicitarios de las empresas, para satisfacer esta novedosa obligación parental (Stearns, 2010, pp 172, 177-8) ${ }^{3}$.

El análisis de las ilustraciones publicitarias implica tomar una serie de recaudos metodológicos. Peter Burke, en un conocido ensayo, ha advertido que muchas veces, al utilizar imágenes, los historiadores las han tomado como "simples ilustraciones" de conclusiones a las que arribaron por otros medios (Burke, 2005, pp 11-24). Por ello al usarlas como testimonios, debemos comenzar por indagar en el objetivo perseguido por sus autores, en este caso la finalidad comercial de vender productos. Pero a su vez, las entendemos también como dispositivos de producción de "tecnologías de género" (de Lauretis, 1996), ya que estas representaciones "articulan/producen significados así como re-presentan un mundo que ya significa” (Pollock, 1990, p 203).

En ese sentido, John Berger ha señalado que la publicidad es efectiva precisamente porque se nutre de lo real. A través de ella, ramas de industria y empresas compiten entre sí, y esta constituye un lenguaje propio que se utiliza siempre con un mismo objetivo: "que nos transformemos, o transformemos nuestras vidas, comprando" (Berger, 2000, pp 71-86). Otros autores, en cambio, han apuntado que para analizar la publicidad es necesario identificar previamente las convenciones del momento, pero a su vez, detectar e interpretar silencios, distorsiones y deformaciones de la "realidad" (Dussaillant Christie, 2016, p 90; Pope, 2003, p 6). Ponemos el foco, entonces, en los usos visuales y textuales del lenguaje publicitario, que reforzaba construcciones sociales, pero las ligaba a consumos particulares, tensionando y distorsionando "lo real".

Para ello analizamos un corpus diverso de publicidades aparecidas en revistas ilustradas de lectura masiva y difusión a escala nacional como Caras y Caretas $(C y C)^{4}$, en diarios de tiraje amplio como El Mundo, así como álbumes de figuritas, catálogos de precios y productos, y publicaciones infantiles producidas por las fábricas de dulces locales entre 1930 y 1943. Estas publicaciones estaban destinadas a un público amplio y eran vistas tanto por adultos (mujeres y varones, madres y padres) como por niñas y niños. $C y C$ fue una revista ilustrada exitosa y verdaderamente popular gracias a su bajo precio ( 20 centavos) y su formato que permitía un fácil transporte y su lectura en trenes o tranvías, y si bien fue un producto de Buenos Aires, circuló ampliamente no sólo en otros centros urbanos, sino en áreas rurales y regiones alejadas del país (Ramos, 1989; Rogers, 2008; Romano, 2004; Szir, 2009, 2013). En sus páginas incluía contenidos dirigidos a la infancia y la familia,al igual que el diario El Mundo, orientado a sectores populares y a la pequeña burguesía, de lectura ágil y rápida, que otorgaba un amplio espacio a la ilustración y la publicidad y se presentaba a sí mismo como "diario moderno, cómodo y sintético", "diario de todo el día para toda la familia", "diario manuable e ilustrado como una revista" o "diario que le interesa a la mujer, al hogar y al niño" (Mangone, 1989; Saítta, 2000). Destinados a un público vasto y masivo, compuesto tanto de trabajadores como de sectores de ingresos medios, y de consumo fragmentario, rápido y extensivo, estos medios aparecen entonces como un espacio 
privilegiado para explorar la difusión de un imaginario publicitario vinculado a la infancia en amplios sectores sociales. Si bien posiblemente adultos y menores vieran cosas distintas en los anuncios, es probable que estos contribuyeran a difundir en el conjunto de los espectadores un horizonte común de ideas, prácticas (como juegos y diversiones) y consumos vinculados a la infancia, así como de obligaciones paternas respecto de los niños, tendientes a satisfacer dichos consumos. Con todo, es importante señalar que este artículo no se propone abordar a fondo la recepción de las publicidades. Hemos trabajado este corpus, compuesto de un centenar de publicidades, registrando los tópicos e imágenes más recurrentes, reproduciendo y tomando para el análisis aquellos ejemplos que fueran significativos de las tendencias generales.

Elegimos esta década para el análisis ya que constituye un momento clave en el proceso de modernización publicitaria y americanización de la sociedad de consumo masivo formada a principios del siglo XX en Argentina (Rocchi, 1998, p 534, 1999). En plena expansión en los años 20, la crisis del 30 profundizó su modernización: la intensificación de la competencia durante la depresión económica fortaleció a las agencias que aplicaban los métodos más vanguardistas de sondeo del mercado, en un contexto de desembarco local de grandes agencias publicitarias norteamericanas y británicas (Rocchi, 2003, 2016, 2017; Salvatore, 2005). Pero la crisis no sólo marcó un hito en el desarrollo económico, publicitario y de la sociedad de consumo en Argentina, sino que a su vez, como ha señalado Isabella Cosse, las ideas y nociones de la infancia y la familia estaban en plena mutación (Cosse, 2005, 2006), lo cual impactó en la dinámica publicitaria, particularmente de los productos para niños. El periodo abordado se cierra en vísperas del peronismo, que implicó grandes cambios en el mundo del consumo, pero también en las nociones de infancia y familia (Cosse, 2006; Elena, 2011; Milanesio, 2014; Pite, 2013).

\section{El MERCADO INTERNO: CONSUMO, EXPANSIÓN Y SEGMENTACIÓN DE LA PRODUCCióN}

La difusión de pautas publicitarias a escala nacional en Argentina se relaciona con un proceso más amplio, el de la formación de un mercado nacional de productos alimenticios, y de galletitas, chocolates y dulces en particular ${ }^{5}$. Este proceso fue liderado por fábricas locales ubicadas en la Ciudad de Buenos Aires, que hegemonizaron el mercado interno desplazando exitosamente a sus pares importados entre los consumidores de bajos y medios ingresos. De este modo se transformaron en grandes fábricas, como es el caso de las productoras de galletitas y bizcochos Bagley y Canale, o las chocolaterías Águila Saint, Godet o Noel (Rocchi, 2006; Scheinkman, 2017a).

Fernando Rocchi ha reconstruido el agresivo proceso por el cual las principales fábricas porteñas lograron consolidar su control del mercado interno. Para capturar la demanda, estas se volcaron a estrategias comerciales como la reducción de precios o la publicidad, que ocupó desde la década del 10 un papel central para la conquista, expansión y consolidación de ese mercado (Rocchi, 2006, pp 121-151).

Algunas cifras elocuentes del consumo de chocolate permiten apreciar el éxito de estas estrategias: en 1914, se habían importado 1.056.101 kilos de cacao para ser elaborados localmente en la industria, y solo 284.035 kilos de chocolate y cocoa ya elaborados. En 1928, se había cuadruplicado la importación de cacao (4.617.311 kilos), y la de chocolates terminados se había reducido en un 65\% (98.847 kilos). En 1943, ya en el contexto de guerra, se habían importado 7.561.685 kilos de cacao, y no se habían importado chocolates terminados (Scheinkman, 2017a, p 121). Además, si a fines del siglo XIX, el consumo anual de chocolate por persona era de 98 gramos, hacia 1914, en poco menos de 20 años, ese volumen se había casi duplicado (170 gramos por persona al año). En 1943, el consumo alcanzó a 390 gramos per cápita, cuadruplicándose. Es decir que si a fines del siglo XIX el chocolate era un consumo infrecuente, hacia mediados del siglo XX la ingesta se había expandido y difundido, advirtiéndose una transformación en la estructura de la demanda, y una popularización y difusión de su consumo (Scheinkman, 2017a, p 138; sobre el consumo de cacao ver también Rocchi, 2006, p 54). Aunque no disponemos de estadísticas de producción y consumo de otros dulces, los indicios apuntan a un similar crecimiento en su consumo. 
Algunos trabajos han planteado que la expansión del consumo en los años de entreguerras se debió al crecimiento de las clases medias, y al aumento del salario real de los trabajadores (Rocchi, 1998, 2003, 2006). Otros trabajos, basados en distintas series salariales, han señalado que el aumento en el salario real de los trabajadores en el periodo de entreguerras fue más moderado de lo que se había supuesto, si se lo compara con el incremento percibido a fines del siglo XIX (Cuesta y Vence Conti, 2014) ${ }^{6}$. Las estadísticas de salario real obrero en la Argentina para la primera mitad del siglo XX muestran un aumento continuo, paulatino y moderado del salario tras la fuerte caída producida durante la Primera Guerra Mundial, con descensos en momentos de crisis económicas y guerras mundiales. Esto permitiría sostener la hipótesis de un gradual pasaje del consumo de alimentos baratos a otros "suntuarios" o de mejor calidad, que se volvieron más accesibles y corrientes.

Es posible, asimismo, que la expansión del consumo de cacao y sus derivados en los años 30 se explique por el fuerte descenso en el precio mundial de las materias primas (que morigeró la caída del salario real en la década del 30), y en particular del cacao, lo cual popularizó y expandió el consumo de este producto. Christopher L. Gilbert ha mostrado que entre 1900 y 1970 hubo una curva en U en el precio real del cacao, cuyos valores mínimos se ubican precisamente en la década de 1930 (Gilbert, 2016).

Así parecía confirmarlo el descenso de los precios y el aumento de la competencia entre productores de dulces tras la crisis del 30. Jacobo Ivitz, Protesorero de la Comisión Directiva de la cámara patronal Asociación fabricantes de dulces, conservas y afines, manifestaba en 1937 que en los años 30 había ocurrido una "verdadera batalla sin cuartel en los precios de dulces y conservas en general", particularmente visible en productos como el dulce de membrillo, "postre nacional". Este último, "que tan franco favor le dispensa el público consumidor", había llegado a venderse a precios tan reducidos que ponían en jaque los réditos económicos de las empresas. La causa de esto era la "superproducción" y el descenso de los precios del membrillo "con las consiguientes pérdidas para los capitales industriales" 7 . En el mismo sentido apuntaban las declaraciones del fabricante Curt Uhlitzsch, Suplente de la Comisión Directiva de la asociación patronal, quien también advertía con preocupación el descenso de las utilidades empresarias por los bajos precios de los chocolates y el aumento de la competencia en la rama. Desde el crack del 29, afirmaba, esta industria soportaba una situación de "verdadera crisis, provocada por la superproducción de toda clase de chocolate, que no deja utilidades de ninguna clase a las grandes fábricas del ramo" ${ }^{8}$.

Si bien las apreciaciones de los directivos de la cámara patronal estaban orientadas por el deseo de cartelizar la producción para aumentar los precios y mitigar la reducción de las utilidades, dejaban entrever que, sin dudas, en la década del 30, superada la crisis, los ganadores fueron los consumidores de menores recursos. Estos lograron acceder a consumos como chocolates o galletitas de mayor calidad, de los que anteriormente habían estado excluidos, incorporándolos a la canasta básica. Ahora bien, si los precios y salarios posibilitaron el consumo de alimentos más refinados, no explican en sí mismos por qué el presupuesto obrero se volcó hacia el consumo de dulces en particular. Por ello es importante analizar también el papel que en la construcción, consolidación y expansión de un creciente mercado de consumo, tuvieron los avisos y las publicidades producidas y distribuidas por las fábricas más importantes. En ese sentido, la conquista del mercado requirió no solamente de una transformación técnica y productiva que permitiera producir a gran escala, incrementar la producción y reducir los precios (Scheinkman, 2017a), sino también de una diversificación de los productos y una segmentación y expansión de los consumidores, a quienes se trató de cautivar con estrategias publicitarias novedosas, y que tuvo a niños y niñas como sujetos centrales.

\section{Publicidades e infancia en la déCAda DeL ' 30}

En la década del 30 en Argentina, las golosinas, chocolates y dulces tenían como destinatarios principales a los consumidores infantiles, y en segunda instancia, a las mujeres. Pero a comienzos de siglo eran aún 
productos lujosos y caros, destinados a consumidores acaudalados -los únicos para quienes eran accesibles de forma habitual-, sin distinción de edad ni género. Esto comenzó a transformarse en la década del 10 cuando se orientaron cada vez de forma más decisiva a mujeres, niños y niñas, en anuncios dirigidos a las madres, que trataban de persuadirlas de alimentar a sus niños con estos productos, resaltando su valor alimenticio y saludable. Hacia los años 20, si bien se mantuvo en los avisos la preeminencia de las mujeres, niñas y niños, los tópicos centrales utilizados para apelar y convencer a las madres de adquirir estos productos se estructuraron en torno a la familia, la crianza, la educación y la vida doméstica. Además, fueron ligando el consumo de dulces ya no tanto con su carácter alimenticio y saludable, sino con su propiedad de "golosinas" que proporcionaban placer, felicidad, unión familiar y educación. Estas publicidades, asimismo, difundieron un modelo de familia nuclear "perfecta", reunida en escenas hogareñas y familiares, y a su vez propagaron nociones de felicidad que fueron ligándose a la infancia y a esta vida doméstica (Scheinkman, 2017b).

Los años treinta y cuarenta fueron tiempos de cambio en las concepciones de la infancia y la familia, y estos cambios se reflejaron en los anuncios. Por un lado, se acentuó la preocupación por la "denatalidad" ya presente en décadas anteriores ${ }^{9}$. Por otro lado, muchas de las ideas que habían regido las concepciones de la infancia, así como las políticas públicas para intervenir en ella, se hallaban en transformación. Como ha señalado Cosse, se proyectaron ideas de pureza e inocencia al universo infantil como un todo, independientemente de su entorno; se comenzó a rechazar la idea de separar a los niños de sus madres y del ambiente familiar; y se delinearon políticas destinadas a las madres y familias en su conjunto (Cosse, 2005, p 50). Estas políticas de asistencia social buscaban erosionar la existencia de dos áreas escindidas, unificando aquellas destinadas a los niños "normales" y a los "menores", la infancia en riesgo y carenciada. A su vez, en estos años se expandieron también, desde distintos sectores, iniciativas educativas, recreativas y pedagógicas orientadas a los niños.

Junto a las ideas de "pureza" e "inocencia" infantiles, se fue consolidando la noción de la infancia como una etapa vital que requería espacios, divertimentos, consumos y cuidados diferentes a los del adulto ${ }^{10}$. Por eso mismo, se extendieron y generalizaron ciertos consumos - dulces y golosinas, revistas, juguetes- y prácticas -juegos, lecturas, diversiones-, que si bien habían estado presentes entre la infancia acomodada, ahora debían ser propias de todo el universo infantil. En efecto, la idea de un único destino común para toda la infancia cobró fuerza en el periodo, contribuyendo a erosionar las representaciones opuestas entre niños hijos-alumnos, menores-abandonados y delincuentes, e hijos-trabajadores (Zapiola, 2009, p 71). Sin embargo, las líneas de clase continuaron dividiendo a la infancia, no solo en el acceso a consumos y juegos ahora considerados "universales", sino también en cuanto a los trayectos institucionales que recorrieron (escuela, asilo, fábrica), y las ocupaciones que tuvieron (estudio, trabajo, ocio).

Este nuevo énfasis en la diversión y el esparcimiento como actividades propias de los niños cobró un lugar preeminente en las publicidades, que desarrollaron in extenso el tópico de la felicidad infantil y lo difundieron y masificaron en publicaciones de diverso tipo y gran alcance. En efecto, en estos años aparecieron en los anuncios algunos rasgos perdurables, asociados aún hasta hoy a la infancia, como los juegos y recreaciones, que se plasmaron en las publicidades y consumos orientados a los niños (algunas continuidades pueden observarse a través del análisis de Minzi, 2006).

La fábrica de chocolates Águila fue pionera en este aspecto y desde los años 20 produjo material educativo y recreativo infantil para difundir sus dulces. Su revista escolar Colibrí fue un recurso publicitario y didáctico editado de manera regular entre 1921 y $1932^{11}$. Colibrí afirmaba ser la revista escolar de mayor tirada del idioma castellano, y publicaba cuentos, historietas, poesías, "lecciones de moral", "lecturas selectas", geografía, entretenimientos científicos, chistes, y colaboraciones de los "intelectuales más prestigiosos del mundo". "COLIBRI no se vende. Se entrega gratis a cambio de 20 etiquetas de Chocolatines AGUILA cada ejemplar. Coleccione esta amena e instructiva revista", anunciaba ${ }^{12}$. Pero aunque afirmaba serlo, no era gratuita. Para adquirirla era necesario consumir 20 chocolatines al mes cuando la publicación era mensual, y luego el doble, lo cual requería un importante presupuesto, inaccesible a consumidores obreros o de bajos recursos. $\mathrm{Al}$ ser coleccionable, su consumo no se satisfacía en sí mismo sino que cada compra generaba una nueva demanda 
para completar la colección. En la tapa del primer ejemplar, una ilustración de Sarmiento asentaba la finalidad cultural y pedagógica que la animaba (Imagen 1).

IMAGEN 1

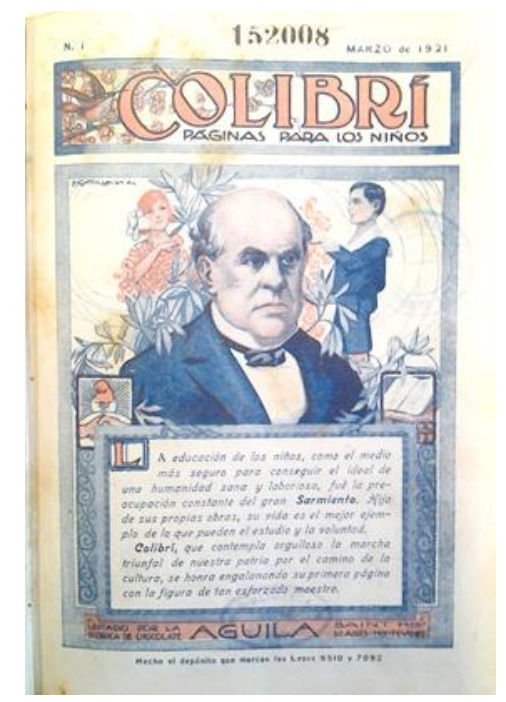

La fábrica de chocolates Águila, desde los años '20, se orientó a la producción de material educativo y recreativo para niños. Colibrí, 3/1920

IMAGEN 2

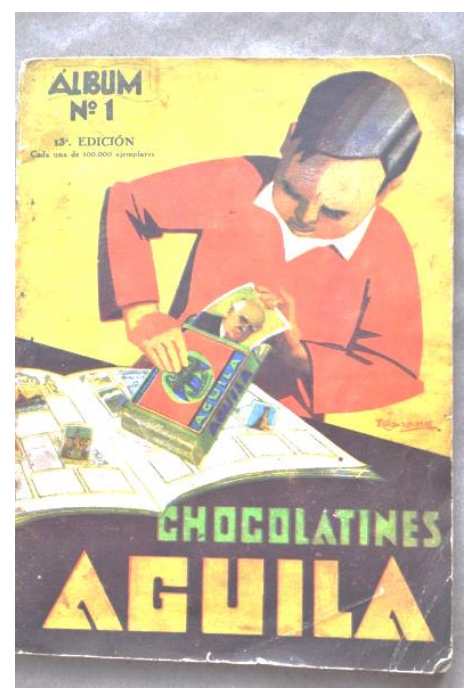

Chocolatines Águila. Álbum Nº1, s.f. (ca. 192 )

\section{IMAGEN 3}

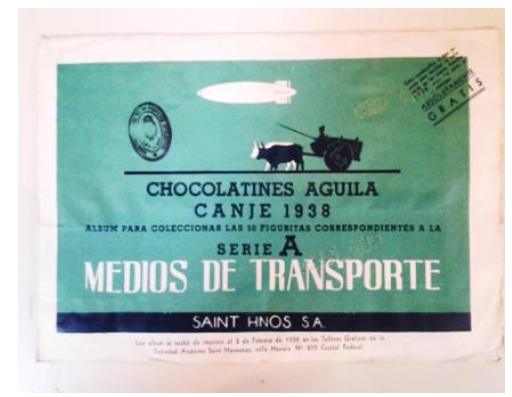

Álbum de figuritas Serie A. Medios de transporte, 1938 
Aunque hay algunos antecedentes, los premios, concursos y figuritas destinadas a capturar al público infantil se difundieron y multiplicaron en los años 30, tornándose en la tónica predominante en las publicidades de dulces ${ }^{13}$. Uno de estos antecedentes fue el Álbum $N^{\circ} 1$ editado por Águila en la década del 20. En línea con su intención pedagógica, agrupaba figuritas coleccionables con temáticas patrióticas: próceres de la independencia, ruinas y sitios históricos, paisajes argentinos, tejidos aborígenes en telar, naturalistas rioplatenses, entre otros (Imagen 2). En su portada podía observarse la imagen de un niño coleccionando y pegando figuritas, es decir, pautando y definiendo una forma de ocio y de consumo del producto, cosa que también hicieron otras marcas ${ }^{14}$.

Águila continuó con esta línea en los años 30, publicando álbumes sobre la historia argentina, pero la centralidad pedagógica previa fue dando paso a otra decididamente orientada al entretenimiento, como en las Series A y B de transportes (1938, Imagen 3), o una colección de libros educativos y recreativos que buscaban interpelar los intereses de niños y niñas: La vida de los animales (1935), La vida de las plantas (ca. 1935), Las aventuras de Pirucho (ca. 1935), o Tartarín de Tarascón, de Alphonse Daudet (ca. 193 ).

El futbol tuvo también importante presencia en sus álbumes coleccionables de 1926 y 1932, que reunían a las estrellas y escudos de los cuadros. Esto se vincula con la popularización de los clubes de fútbol en los años 20, su apropiación identitaria infantil, juvenil y barrial y su profesionalización en la década del 30 (Frydenberg, 2011) ${ }^{15}$. Varias marcas se publicitaron con álbumes y figuritas con temáticas de fútbol, y los premios solían incluir pelotas para practicar este deporte. En los años 40 la marca de cacao en polvo Toddy incluso organizaba y auspiciaba campeonatos de futbol infantiles, eventos masivos a los que asistían los niños en sus equipos barriales acompañados por sus padres, tal como lo anunciaba el diario comunista La Hora. Los pequeños lucían en sus casacas el logo de la marca, y las fotografías fueron reproducidas en periódicos, operando como una forma extra de publicidad (Imagen 4).

\section{IMAGEN 4}

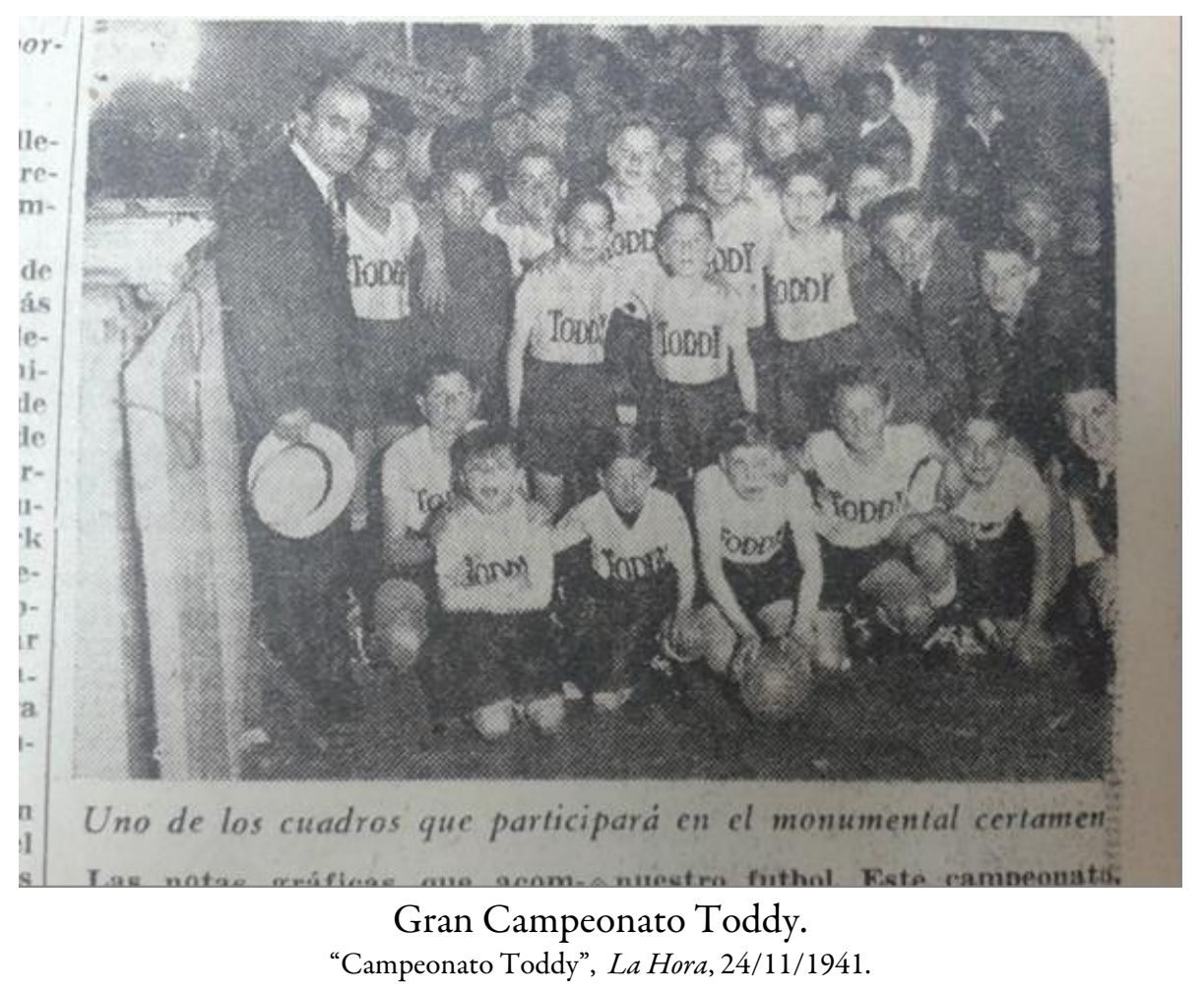

Esta estrategia publicitaria que apelaba a los gustos infantiles parece haber sido exitosa, ya que todas las grandes marcas la reiteraron, en una agudización de la competencia probablemente incrementada por la fuerte crisis económica a comienzos del 30. Además, la presencia renovada de una empresa extranjera, la 
multinacional Nestlé, que inauguró la fabricación local en 1931 con una gran planta ubicada en Buenos Aires, puede haber intensificado la competición publicitaria, a raíz de los intentos de la firma suiza por ganar terreno en el mercado local. Esta competencia se plasmó en la multiplicación de recursos publicitarios, premios, promociones y avisos, que ubicaron al niño como sujeto privilegiado de consumo. Por ejemplo Nestlé anunciaba, en 1933, el éxito de las figuritas de su álbum "Las maravillas del mundo", y comunicaba que había tenido que tomar "medidas pertinentes para terminar con el acaparamiento de sus famosas figuritas, alrededor de las cuales se había formado un verdadero comercio: eran substraidas de la circulación por medios diversos, y luego ofrecidas a buen precio a quien las necesitase para completar el álbum..." (Imagen 5).

Aunque dicha publicidad probablemente exagerara la desesperación infantil por estos productos, daba cuenta del gusto infantil por los coleccionables y las figuritas, y de la práctica del comercio y el intercambio, que se alejaba de la utilización ideada y esperada por la empresa, llegando incluso al acopio y la especulación. Los chocolatines parecían ser solo una excusa para completar los álbumes y para el juego organizado en torno al intercambio de figuritas. Sin embargo, Nestlé pretendía ser la favorita del público, y afirmaba complaciente: "la decidida preferencia por los productos Nestlé de parte del público, [que] nos pone en condiciones de retribuir más ampliamente aún su adhesión” con un gran sorteo.

\section{IMAGEN 5}

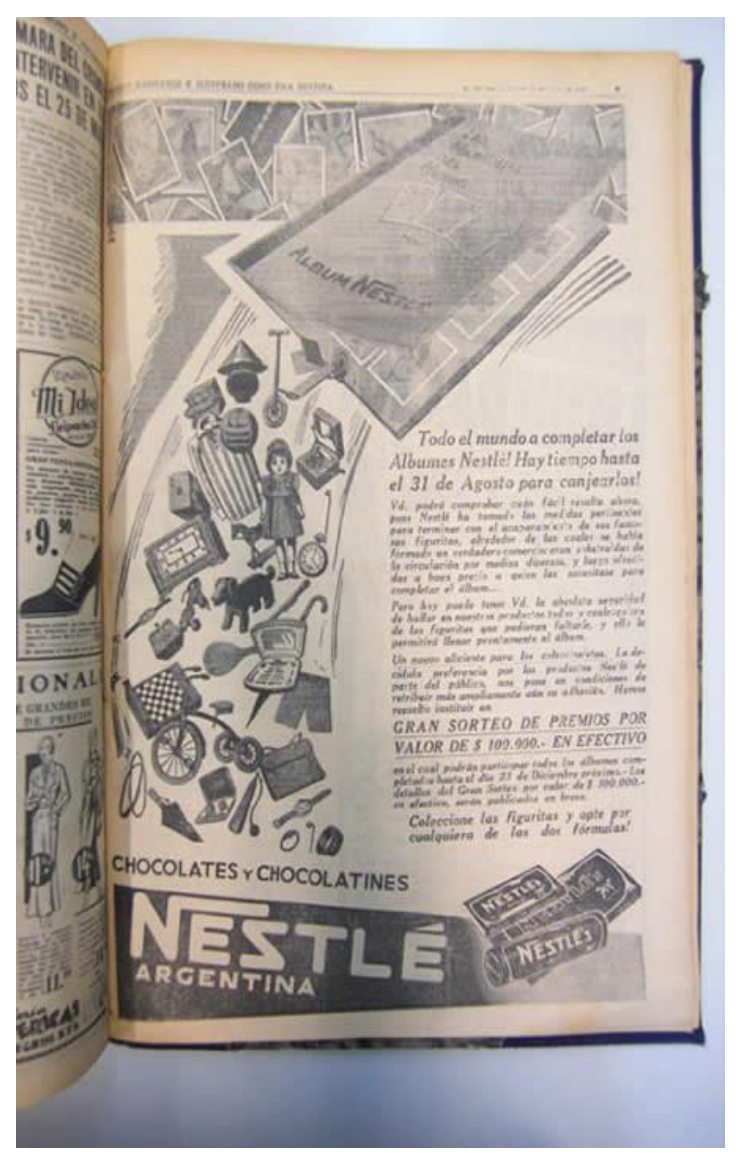

En los años 30, los destinatarios de los avisos comenzaron a ser los niños. Se les hablaba directamente, y se recurrió recursos para "seducirlos": concursos, figuritas, álbumes, premios. 


\section{IMAGEN 6}

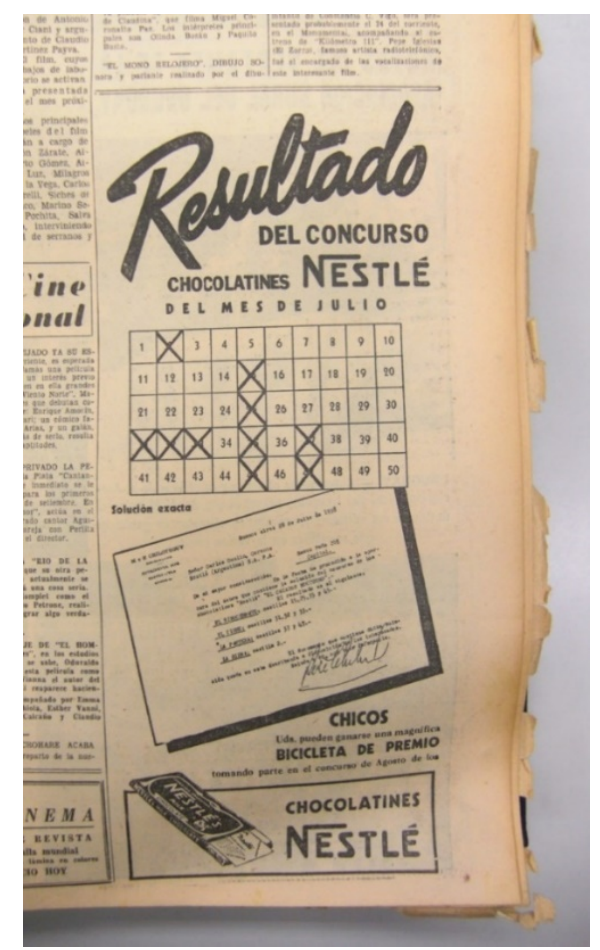

El Mundo: diario ilustrado de la mañana, 15/8/1938

\section{IMAGEN 7}

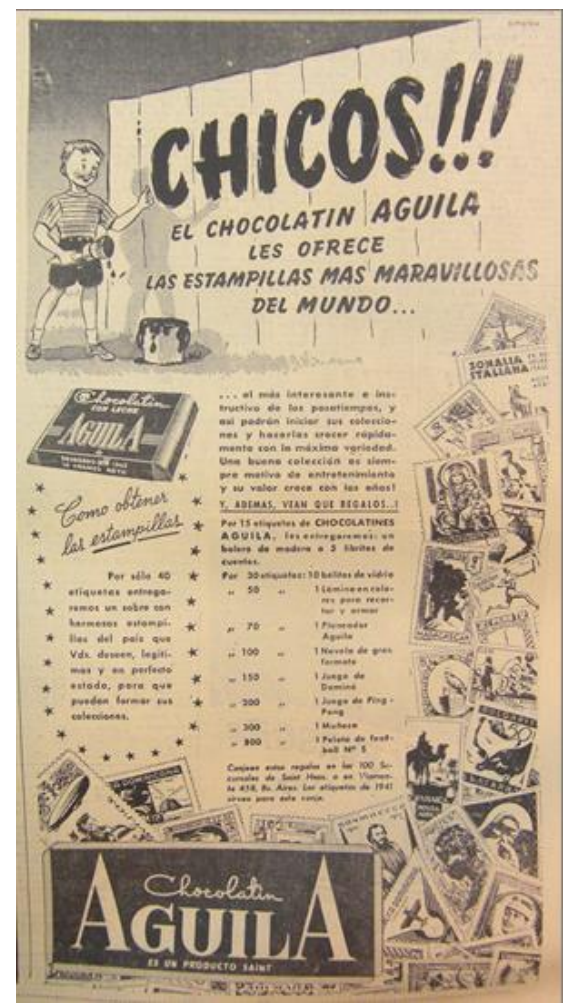

El Mundo: diario ilustrado de la mañana, 11/3/1942 


\section{IMAGEN 8}

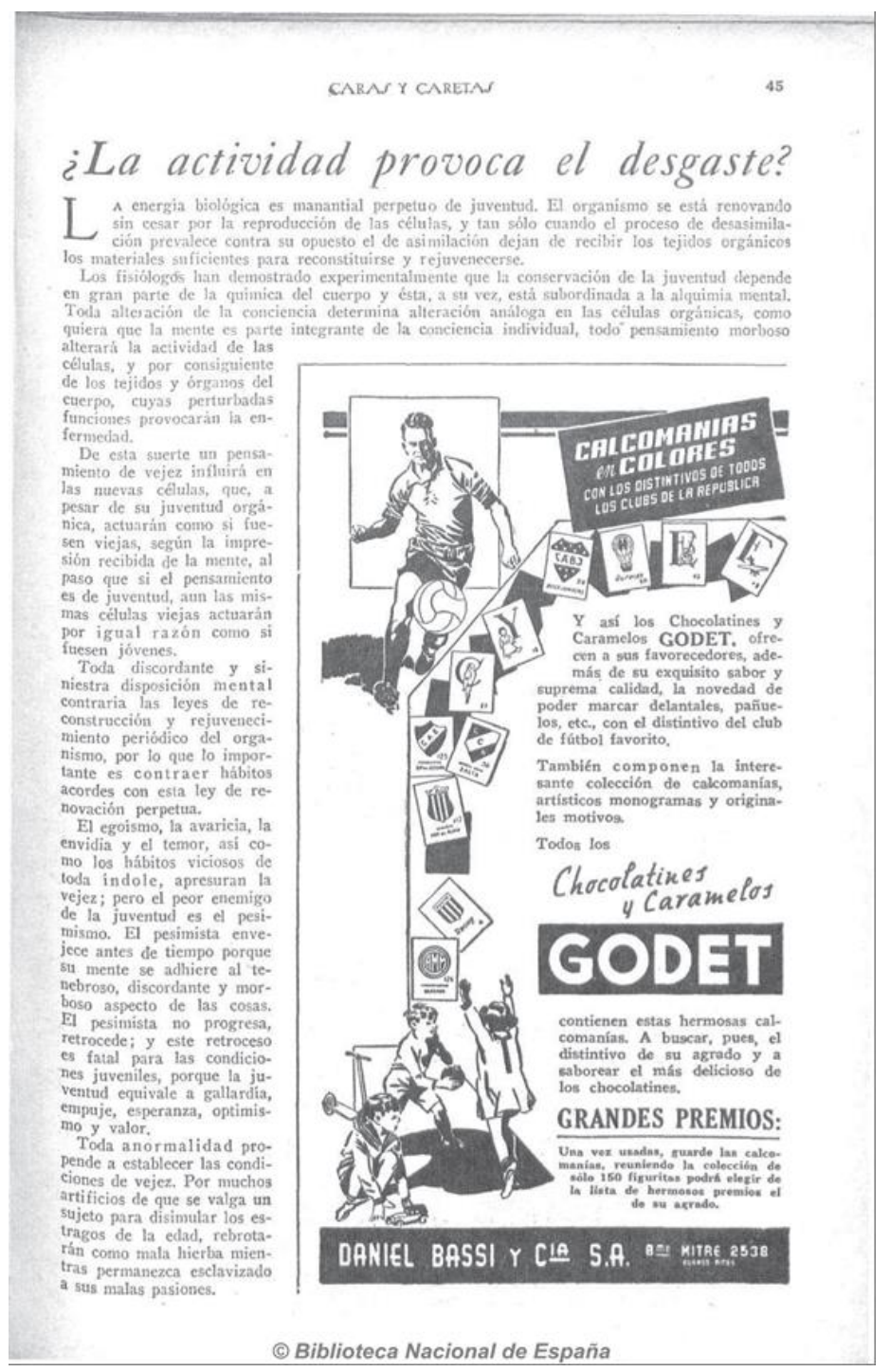

CyC, 18/9/1937: "los Chocolatines y Caramelos GODET, ofrecen a sus favorecedores, además de su exquisito sabor y suprema calidad, la novedad de poder marcar delantales, pañuelos, etc., con el distintivo del club de fútbol favorito. (...) guarde las calcomanías, reuniendo la colección de sólo 150 figuritas podrá elegir de la lista de hermosos premios."

En efecto, la gran apuesta publicitaria de las fábricas de dulces en los años 30 fue la conquista del consumo infantil, ahora dirigiéndose directamente a los niños, y la característica saliente de esta década fue la emergencia de los niños como agentes de consumo. En ese sentido, se desarrolló una tendencia que ya había aparecido de forma incipiente en los anuncios de dulces en los años 20, en el marco de un fenómeno más amplio de emergencia de los niños como consumidores, a quienes habían apostado ya otras empresas, como es el caso de Billiken que abrió el camino de los "niños consumidores", no sólo de lecturas sino también de otros productos (Bontempo, 2012, 2015; Scheinkman, 2017b). De forma novedosa, las publicidades del periodo se destinaron y dirigieron ya no a las madres, sino directamente a los niños como sujetos de consumo a los que era necesario conquistar. En 1938, en el diario ilustrado El Mundo, Nestlé hablaba directamente a los niños lectores: "Chicos: Uds. pueden ganarse una magnífica bicicleta de premio tomando parte en el concurso de Agosto de los Chocolatines Nestlé” (Imagen 6). Pocos años después, los chocolatines Águila se publicitaban de la misma manera: "Chicos!!! El chocolatín Águila les ofrece las estampillas más maravillosas del mundo... el más interesante e instructivo de los pasatiempos" (Imagen 7). Si por un lado las publicidades esperaban estimular los deseos de los pequeños, y por su intermedio, influir en el gasto familiar provocando la compra, 
por otro lado no dejaban de reconocer la existencia de una considerable autonomía entre los niños y niñas, quienes aparecían con gustos propios, capacidad de decisión y cierto albedrío a la hora de elegir sus alimentos. Por ello, las publicidades buscaban guiarlos e influirlos en sus decisiones de consumo apelando a sus deseos e intereses supuestos.

Aunque otros productos como las mermeladas, dulces y galletitas también buscaron seducirlos, los chocolatines, pequeñas tabletas de chocolate con leche, fueron los productos destinados de forma privilegiada a los infantes. Por su pequeño formato, eran productos de bajo precio y venta individual más asequibles para consumidores de menores ingresos. Fueron publicitados con envoltorios atractivos, que eran coleccionables por sí mismos o como figuritas para completar álbumes. Las marcas trataban de lograr la fidelidad de sus pequeños consumidores a través de los concursos y álbumes que abordaban diversas temáticas consideradas de interés por los niños: estrellas de fútbol, medios de transporte, animales, etc. Los chocolatines eran relativamente económicos (un chocolatín Godet costaba, en 1938, 5 centavos), y eran por lo tanto un consumo que comenzaba a ser accesible de forma ocasional para sectores tradicionalmente excluidos. Esto anticipaba, en alguna medida, cierta "democratización del consumo" asociada luego al peronismo 16. Sin embargo, completar un álbum implicaba gastar unos cuantos pesos. La Serie A. Medios de Transporte de Águila (Imagen 3), promocionado en 1938, requería de 50 figuritas. La colección Godet de 1937 estaba compuesta por "sólo 150 figuritas", necesarias para poder canjear los premios, lo cual implicaba un gasto mínimo de \$7,50 (Imagen 8). Esto estaba fuera del alcance de la mayoría de las familias trabajadoras .

Por ello, este mayor acceso al consumo podía convertirse rápidamente en carencia, generando una mayor demanda. Los chocolatines y caramelos que publicitaba Godet en 1936, al traer calcomanías coleccionables y álbumes para completar con cuadros de fútbol, jugadores o estrellas de cine local (Imagen 9), demandaban nuevos consumos para poder completar la colección, y esto rara vez ocurría, generando insatisfacción. Por eso Godet trataba de explotar su bajo precio, y en 1938 los presentó como un ahorro o inversión. En grandes y llamativas tipografías, encabezó sus anuncios ilustrados con una niña y un niño comiendo alegres y sonrientes: "Una bicicleta por $5 \mathrm{cts}$. Ya son muchos los agraciados con las hermosas bicicletas que regala GODET" (Imagen 10). A continuación y en letra más pequeña especificaba que sólo algunos chocolatines contenían en su interior la llave para el premio: "el pequeño CUPON, canjeable por una bicicleta, que higiénicamente envuelto en papel celofán ha sido distribuido en muchos de los CHOCOLATINES GODET”. Los chocolatines sin premio, como “enganche”, traían "figuritas en colores, cortadas y engomadas para ilustrar todos los temas del programa escolar, y por cuya colección entregaremos importantes premios. (...) Pida hoy mismo un álbum (...), y empiece la colección”. 


\section{IMAGEN 9}

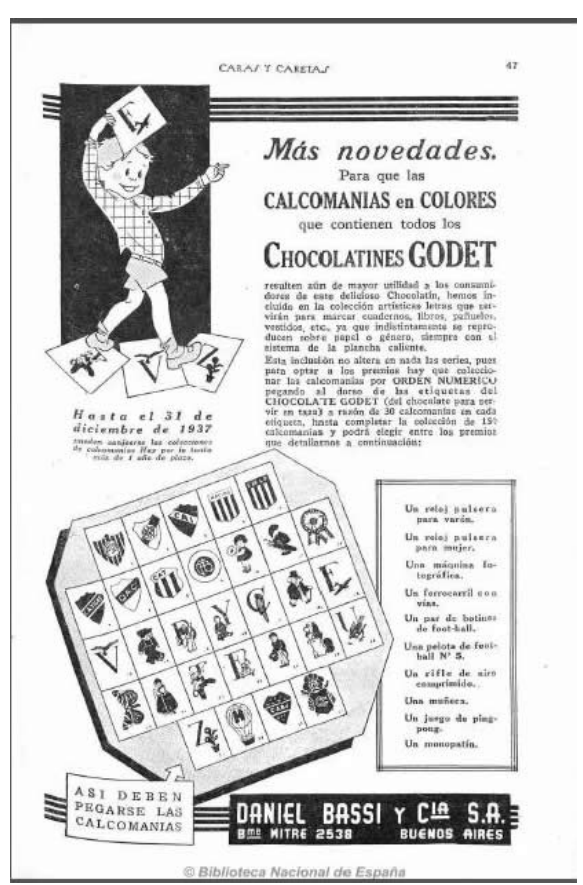

En los años 30 los chocolatines fueron los productos destinados de forma privilegiada a los pequeños.

Eran publicitados con envoltorios atractivos, coleccionables en sí mismos o como figuritas para completar álbumes que abordaban diversas temáticas consideradas de interés para los niños. $C y C, 10 / 10 / 1936$. "Hay que completar la colección de 150 calcomanías y podrá elegir entre los premios que detallamos a continuación: Un reloj pulsera para varón. Un reloj pulsera para mujer. Una máquina fotográfica. Un ferrocarril con vías. Un par de botines de foot-ball. Una pelota de foot-ball $N^{\circ} 5$. Un rifle de aire comprimido. Una muñeca. Un monopatín”

IMAGEN 10

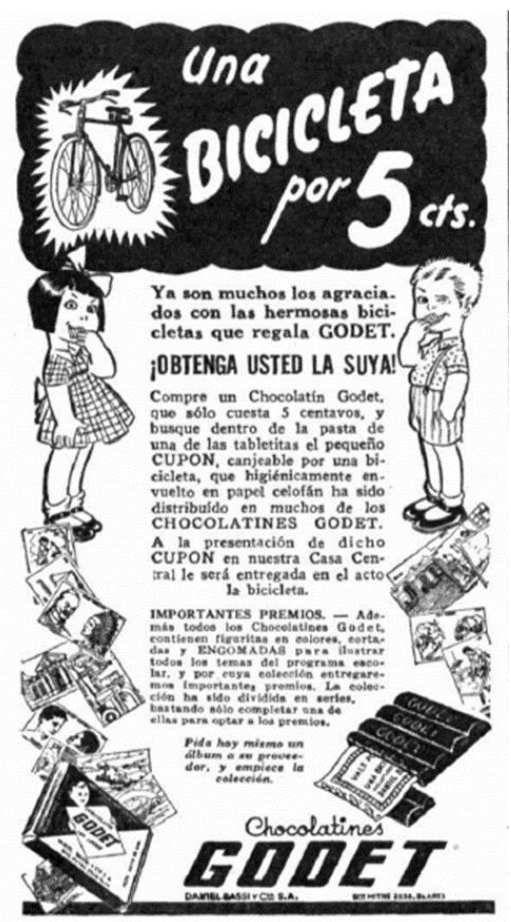

CyC, 9/7/1938 


\section{IMAGEN 11}

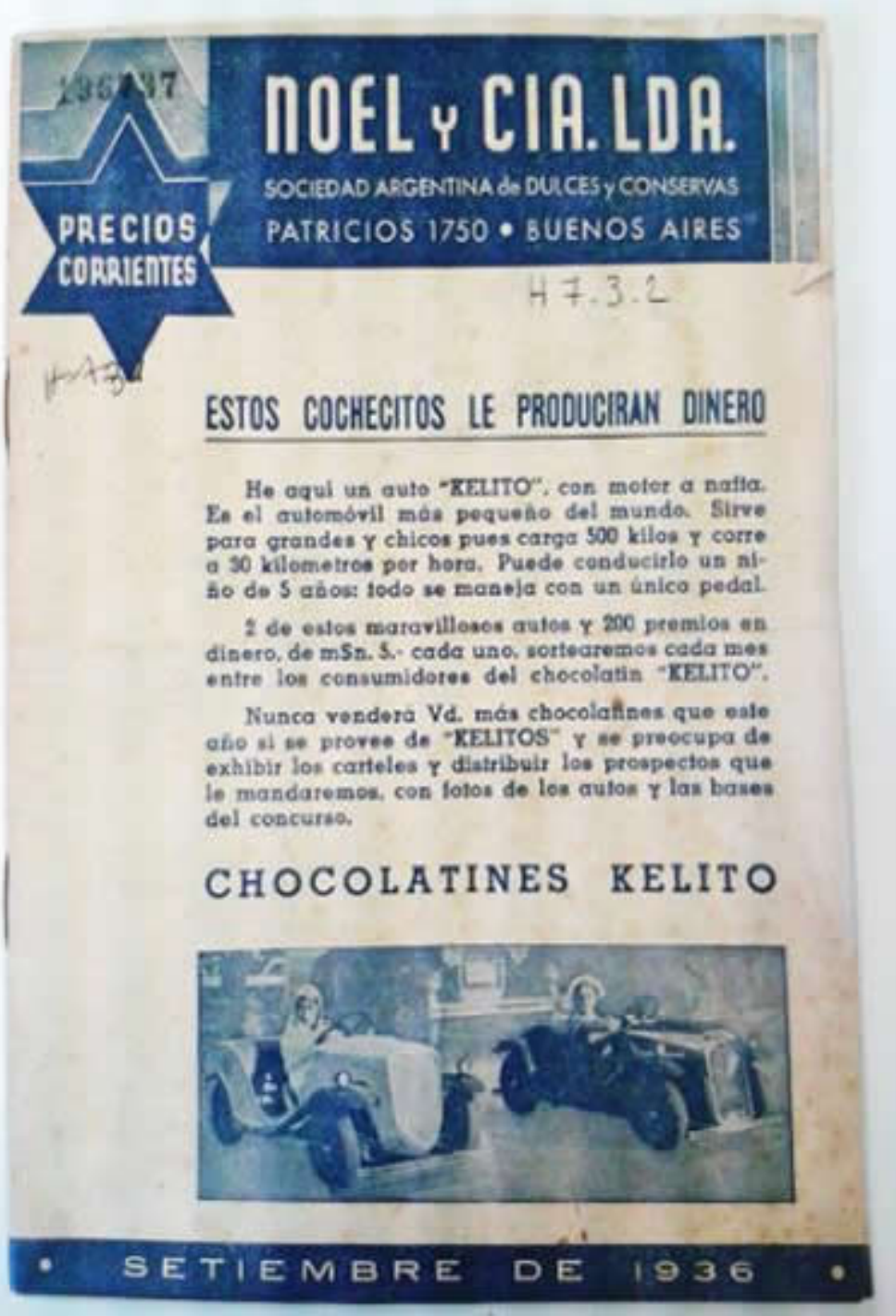

Noel y Cía. Precios corrientes, 9/1936. "Estos cochecitos le producirán dinero. He aquí un auto "KELITO", con motor a nafta. Es el automóvil más pequeño del mundo. Sirve para grandes y chicos pues carga 500 kilos y corre a 30 kilómetros por hora. Puede conducirlo un niño de 5 años: todo con un único pedal" 


\section{IMAGEN 12}

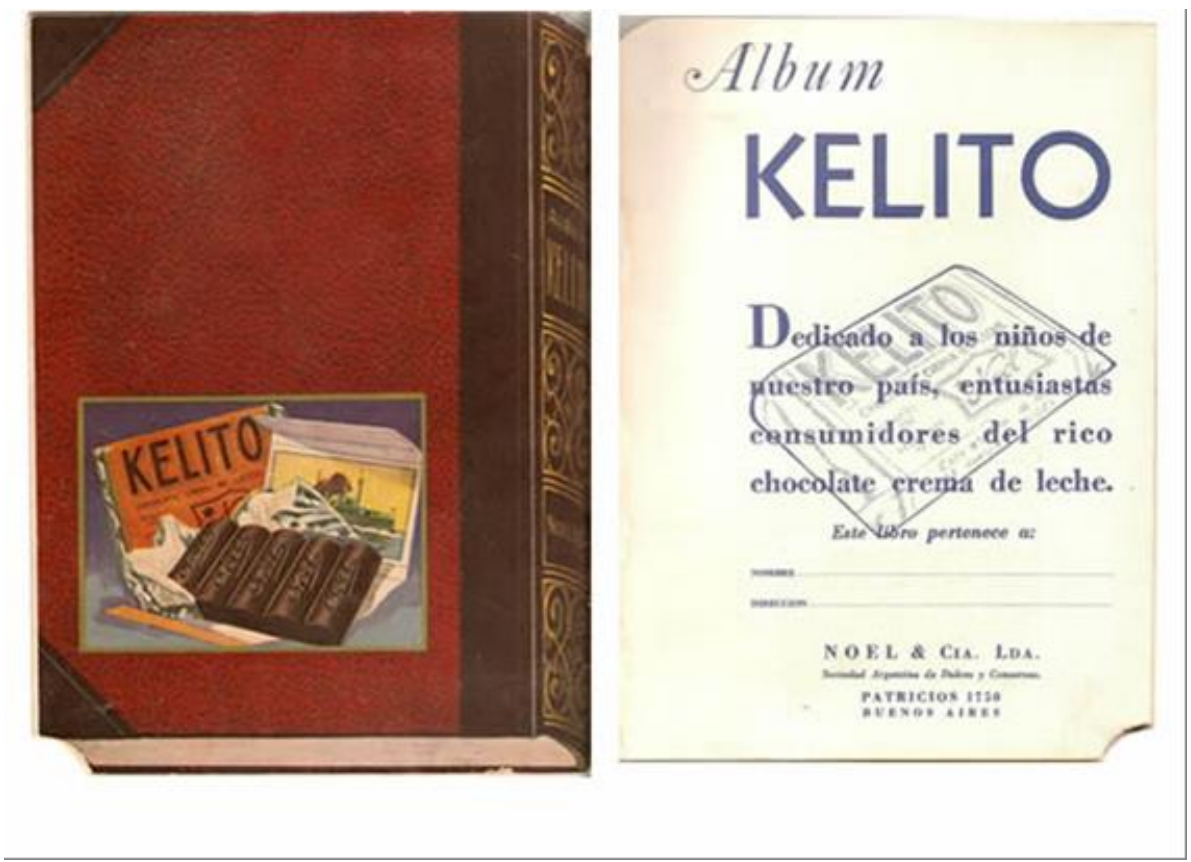

Noel y Cía. Álbum Kelito, 1932.

En 1936, la fábrica Noel apostaba también fuertemente a los chocolatines infantiles, colocando la publicidad de los "Kelito" en la portada de su catálogo de productos y precios corrientes de dicho año. La empresa se comprometía a sortear 2 pequeños autos por mes y 200 premios de $\$ 5 \mathrm{~m} / \mathrm{n}$ cada uno entre los consumidores. Estos novedosos premios prometían atraer más consumidores que nunca, y con ese anzuelo los fabricantes esperaban que los almaceneros y comerciantes al por menor sugirieran los productos exhibiéndolos vistosamente: "Nunca venderá Ud. Más chocolatines que este año si se provee de "KELITOS" y se preocupa de exhibir los carteles y distribuir los prospectos que le mandaremos, con fotos de los autos y las bases del concurso" (Imagen 11). En 1932, el álbum Kelito, "dedicado a los niños de nuestro país, entusiastas consumidores del rico chocolate crema de leche" fue sobre clubes de fútbol. Las calcomanías eran ilustradas con los jugadores más reconocidos, y el desafío era completar los equipos (Imagen 12) ${ }^{18}$.

El fútbol, la literatura, el cine y los cortometrajes animados fueron algunos de los rasgos de una cultura identitaria y de consumo infantil que se fue configurando y consolidando en la década del 30, junto a comestibles como las golosinas y los chocolatines, y entretenimientos como los álbumes coleccionables, que la plasmaron y contribuyeron a popularizarla.

Los destinatarios del grueso de estas publicidades eran implícita o explícitamente varones puesto que eran ellos quienes ilustraban la mayoría de los anuncios. En los envoltorios de chocolatines, álbumes de figuritas de fútbol y concursos, los atractivos premios consistían en juguetes, y en ellos aparecía una segregación de los juegos según los sexos: para las mujeres se ofrecían muñecas, mientras que para los varones la oferta se multiplicaba a pelotas de fútbol, armas, autos y trenes. Una publicidad de Godet de 1936 ofertaba como premios libritos de cuentos, bolitas de vidrio, láminas en colores para recortar y armar, un "planeador Águila", una novela, un juego de dominó, uno de ping-pong, una muñeca y una pelota de fútbol (Imagen 9). Algunos de estos eran educativos o podían ser utilizados indistintamente por niños y niñas (libros de cuentos, láminas), pero en su mayoría estaban destinados a los varones, a quienes el mercado ofrecía más variedad de productos (bolitas, pelota, planeador), con excepción de la muñeca, dirigida a las niñas. En ese sentido, estos productos contribuyeron a la naturalización de la segregación y división de roles y mandatos para niñas y niños presente en la sociedad, en tanto para ellas el divertimento se vinculaba con su rol unívoco como futuras madres, mientras que para los niños había una multiplicidad de opciones y destinos que reforzaban un rol activo y 
constructor. En ese sentido, las publicidades interpelaban no sólo a los deseos y gustos infantiles, sino también a los preconceptos de los padres -y fundamentalmente las madres, encargadas de las compras en el hogarsobre los roles y juegos apropiados para los niños y niñas según su género.

Esto se relaciona con una estrategia propia del registro publicitario identificada por Roland Marchand en su estudio sobre el marketing y la sociedad de consumo en Estados Unidos entre 1920 y 1940, denominada la "parábola de la democratización de los bienes". Esta consistía en dirigir las publicidades a "todo el mundo", enfatizando que gracias a la moderna producción en masa y el consecuente abaratamiento de los precios, "todos" podían acceder a los más significativos placeres, comodidades y beneficios, antes restringidos a la minoría más acaudalada de la sociedad, promoviendo así una suerte de "democracia" en términos de igualdad de acceso a bienes de consumo (Marchand, 1985, pp 217-222). Por ello convivían en los avisos marcas de distinción con apelaciones a consumidores de menores recursos. Fueron muchos los anuncios de dulces del periodo que apelaron a "todo el mundo" (Imagen 5), o a "todos" los "chicos" (Imágenes 6 y 7), dando a entender que estos productos, antes inaccesibles, eran ahora asequibles a todos los niños y niñas por igual gracias a su bajo precio ( 5 centavos). Además, mediante los concursos y premios, prometían que permitirían a "todos" acceder a juguetes exclusivos antes inaccesibles, tales como bicicletas ("Una bicicleta por 5 cts", Imagen 10) o el pequeño automóvil con motor a nafta promocionado por Kelito (Imagen 11). La contracara de estas afirmaciones y de la misma parábola era, por un lado, que no "todos los chicos" podían acceder a estos consumos. Y por otro lado, que aquello que las publicidades mostraban como la aspiración universal de la infancia, estaba atiborrado de marcas de clase, género y raza. Las vestimentas, ocupaciones y viviendas de los niños representados en los anuncios correspondían a una clase media o media alta (Imágenes 2, 7, 9, 10, 11, 13-15) (sobre las clases medias ver, entre otros: Adamovsky, 2015; Hora y Losada, 2011; Míguez, 1999). En ellos se veían casas amobladas, mesas, cortinas, ventanas, manteles y mascotas, no ya opulentos como los de los años 20 (Scheinkman, 2017b), pero que sin dudas estaban por encima de las posibilidades de buena parte de la población; escolares de uniforme o niños dedicados de modo prioritario al juego (y no al trabajo, aunque el trabajo infantil era aún parte de la vida cotidiana de los niños y niñas de familias obreras); imágenes de cuerpos de niños y niñas blancos y rozagantes, que promovían estándares raciales y universalizaban parámetros de belleza ligándolos a criterios de clase; juguetes publicitados para "todos los chicos", pero destinados de hecho a los varones, para quienes la oferta de diversiones era amplia, activa y dinámica y acaparaba la mayor parte de las publicidades, universalizando ciertos entretenimientos como el fútbol, y prescribiendo de hecho valores, gustos, espacios y divertimentos diferenciales para niñas y niños. La parábola de la democratización de los bienes, por lo tanto, presentaba como universales ciertos deseos, consumos, formas de vida y vidas dignas de ser vividas, las publicitaba y difundía, pero llevaba como contracara la marca de la exclusión.

Además de a las diversiones y entretenimientos infantiles, las publicidades apelaron al placer y goce que podrían obtener consumiendo estos productos ${ }^{19}$. En las gráficas con que Bagley difundió sus dulces y mermeladas, aparecían niños rosados de apariencia saludable chupándose los dedos manchados de dulce: "cuando a un niño dais placer, en las sendas del cielo alegres campanas hacéis tañer" (Imagen 13), rezaban los versos que acompañaban ${ }^{20}$. El mensaje era claro: la adquisición de productos por parte de los padres era una garantía para obtener el placer y la felicidad de sus hijos. 


\section{IMAGEN 13}

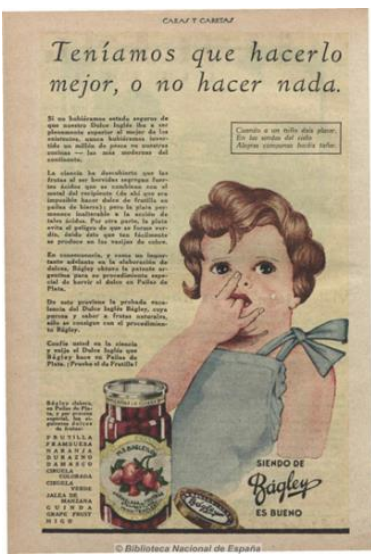

Los anuncios enfatizaban el gusto, la exquisitez, el goce y placer obtenidos en el consumo. En ellos, se mostraba a niños hambrientos y felices. Los adultos, muy presentes en las publicidades en los '20, desaparecieron de los anuncios dando paso a la configuración de un "mundo de niños". CyC, 22/8/1931

IMAGEN 14

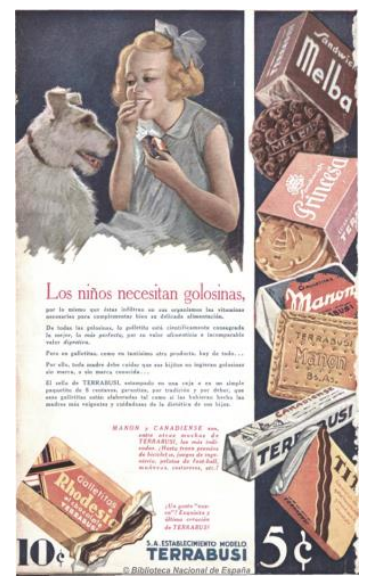

CyC, 28/3/1936

IMAGEN 15

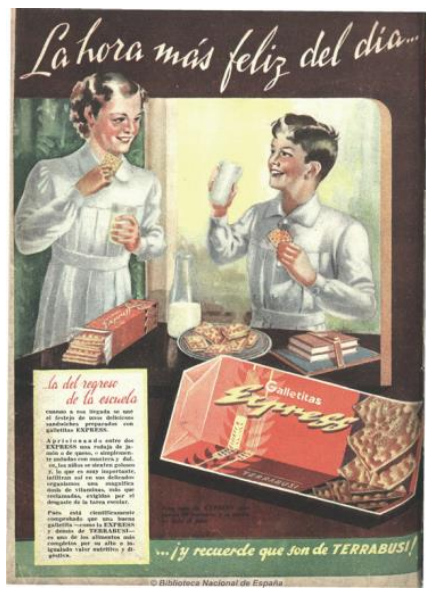

CyC, 10/6/1939

La fábrica Terrabusi publicitó asimismo en 1936 sus productos característicos (las galletitas Melba, Manon, y las obleas bañadas en chocolate Tita y Rhodesia, entre otros), con la imagen de una niña 
comiendo gustosa y golosa, mientras su perro la observaba atentamente, bajo el slogan: "Los niños necesitan golosinas" (Imagen 14). Además de recalcar el bajo precio de los productos, que costaban "sólo 5 centavos", la empresa hablaba a las madres y hacía énfasis en la marca como garantía de calidad: "en galletitas, como en tantísimo otro producto, hay de todo... Por ello, toda madre debe cuidar que sus hijitos no ingieran golosinas sin marca, o sin marca conocida...". Sin embargo el argumento principal era el delicioso sabor, el "gusto "nuevo"! Exquisito". Una publicidad de galletitas Express mostraba también a dos escolares de uniforme, sonrientes, blancos y rozagantes tomando leche con galletitas, y sentenciaba: " $i L a$ tentación de toda hora para grandes y chicos!” ${ }^{21}$. Este aviso de 1932 fue reiterado en términos similares en 1941 con el slogan: "La hora más feliz del día... la del regreso de la escuela” (Imagen 15). Esta estrategia, que apelaba al gusto y la felicidad de los escolares, resultó ser exitosa y fue aplicada también por otras marcas.

Las publicidades de dulces sugieren entonces la emergencia progresiva de un espacio de mayor autonomía infantil en el marco de las familias con cierto nivel adquisitivo en la Argentina de los años 30. Gradualmente comenzaron a aparecer en las publicidades como demandantes, evaluadores, con gustos propios y capacidad de influir en los gastos familiares, algo que sería característico en años posteriores. Es decir, emergieron como un mercado con consumos y gustos peculiares. En ese sentido es notoria la "invisibilización" de los adultos en los anuncios, que habían estado muy presentes en las publicidades de los años 20, plagadas de escenas domésticas con presencia de padres, madres, abuelos y sirvientes. En los 30, los adultos desaparecieron de los anuncios, o fueron corridos a sus márgenes, para ceder el paso a un "mundo de niños" donde la autoridad adulta parecía inexistente, o bien aparecía para satisfacer el deseo infantil (Imágenes 2, 7-10, 13-15). Este rasgo perdurable hasta la actualidad en los anuncios infantiles posiblemente tuviera como objeto apelar y explotar el deseo infantil de desaparición de toda norma impuesta desde el exterior, apostando a "seducir a los consumidores jugueteando con el deseo de autonomía tan a flor de piel en esa etapa de la vida", como ha puntualizado Viviana Minzi (2006, pp 226-227). Siendo la infancia una etapa en la vida caracterizada por una relación de poder desigual frente a los adultos a cuya autoridad y protección los niños están sujetos, y de quienes dependen económicamente, esta autora señala que los publicistas encontraron una "mina de oro comercial" reconociendo, legitimando y apelando al deseo infantil de autonomía y construyendo una "cultura de oposición" frente a los adultos (Minzi, 2006, p 228). La autonomía infantil promovida, legitimada y difundida por los anuncios era, no obstante, una autonomía para el consumo y el desenvolvimiento en el mercado, y la oposición con el mundo adulto radicaba en las posibles trabas que éstos pudieran oponer a su ejercicio del deseo consumista.

Sin embargo, probablemente esto respondiera no sólo a la voluntad de las empresas de "construir" a los niños como consumidores -y tutelar y guiar sus consumos- sino a transformaciones más profundas en la sociedad y la familia y en el lugar social de los infantes. Es posible que el reconocimiento publicitario de una creciente autonomización e independización de los niños en el hogar, es decir, la emergencia de un creciente espacio para la agencia, las demandas y la acción infantil en el seno familiar, se correspondiera con cambios en el ámbito doméstico y en el accionar estatal sobre la infancia. $Y$, de modo general, con el proceso de "entronización" de la infancia que advirtiera Cosse como plenamente operante al promediar el siglo, en el marco de un proceso más general de "valorización" de la infancia en el mundo occidental (Cosse, 2006; Zelizer, 1994). En ese sentido, el nuevo mandato parental centrado en la obligación de padres y madres de garantizar infancias felices a sus hijos e hijas, instalado en occidente en estas décadas en estrecha ligazón a la difusión del consumismo y el american way of life, legitimaba la adquisición de productos como una de las vías para obtener el placer y la felicidad de niños y niñas (Stearns, 2010). Es posible, por lo tanto, que estos mismos anuncios fueran leídos por los padres y madres en clave de legitimación del juego infantil o de cierto consumo de los niños, y de su necesidad de diversiones y espacios separados de los adultos. En ellos se encerraba a su vez un sentido pedagógico, en tanto indicaban cuál era la forma correcta de alimentar a los niños para proveerles felicidad y ser "buenos padres". 
La preeminencia del consumidor infantil, que dominó las pautas publicitarias, opacó en los anuncios de dulces otros patrones presentes con menor frecuencia, orientados ya no a niños y niñas sino a las mujeres. En la década 30 la apelación femenina se centró en la mujer doméstica, la madre en el hogar, ocupada ahora directamente en la manutención, alimentación y cuidado de sus hijos (Aguilar, 2014; Cosse, 2006; Míguez, 1999). Las publicidades, particularmente de chocolates, mostraron este patrón y proliferaron avisos con recetas de tortas y preparaciones dirigidas a las "amas de casa". Aunque los recetarios de cocina eran recursos publicitarios utilizados por algunas fábricas alimenticias desde los años 20 (Caldo, 2013), las fábricas de dulces, concentradas en el consumo infantil, sólo tardíamente comenzaron a interpelar a las mujeres como “ecónomas" encargadas de la cocina ${ }^{22}$. Una publicidad de 1934, dirigida en primera persona a "la señora", rezaba, "El Chocolate Águila es ampliamente generoso. Basta observar la multitud y variedad de postres deliciosos que usted, señora, podrá hacer con una mínima cantidad de Chocolate Águila. Sus postres tendrán gusto a CHOCOLATE, y a chocolate FRESCO" (Imagen 16). La destinataria de estos avisos no era ya una mujer aristocrática. Ella misma cocinaba, era la encargada de las compras en el hogar y debía hacer rendir el salario del marido. Por eso la publicidad enfatizaba que el chocolate era "generoso", y que con una mínima cantidad podían lograrse preparaciones con verdadero gusto a chocolate, sin invertir un dineral. Los distintos productos, elaborados por la mujer en su propia cocina, aparecían en la ilustración con vista tentadora. Era la intención, pues, extender el consumo hacia sectores de menores ingresos.

\section{IMAGEN 16}

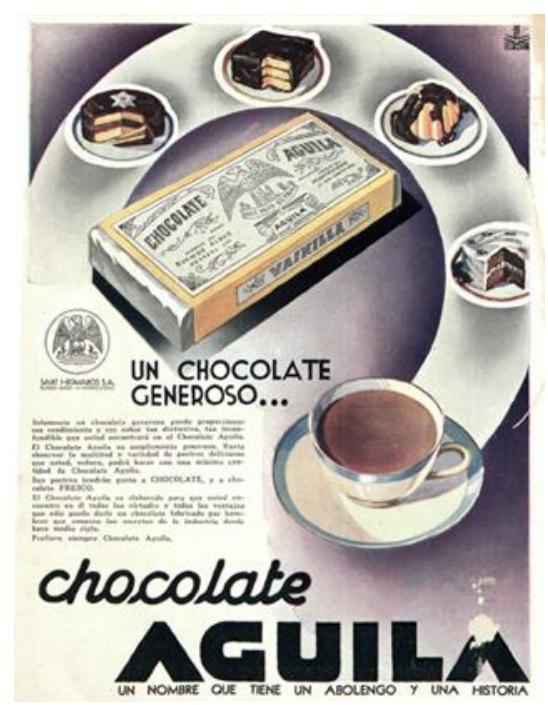

Las fábricas diversificaron sus productos para abarcar consumidoras de menos recursos. CyC, 6/10/1934, 44. 


\section{IMAGEN 17}

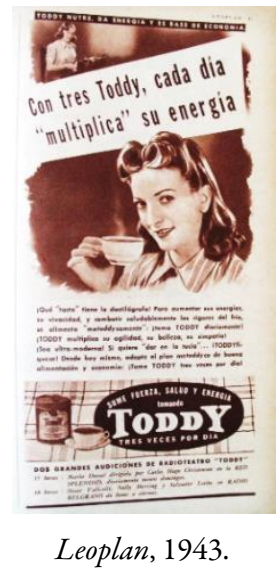

Aunque esta consumidora ideada ya no era una mujer aristocrática, sólo en los años 40 las mujeres comenzaron a ser interpeladas en tanto trabajadoras, como en un anuncio de Toddy de 1943, que hablaba a la dactilógrafa (Imagen $17{ }^{23}$ ): “QQué tacto tiene la dactilógrafa! Para aumentar sus energías, su vivacidad, y combatir saludablemente los rigores del frío, se alimenta "metoddycamente”: ¡ toma TODDY diariamente! ¡TODDY multiplica su agilidad, su belleza, su simpatía! ¡Sea ultra-moderna! Si quiere "dar en la tecla”... ¡TODDYfíquese!”. La figura obrera como destinataria de anuncios apareció en los años 40 y se difundió masivamente durante el peronismo (Elena, 2011; Milanesio, 2014). Estas imágenes, sin embargo, no tuvieron la centralidad en los anuncios dulces que correspondió a los consumidores infantiles, algo que continuó siendo característico en décadas siguientes.

\section{Conclusiones}

En los años 30, los productos dulces se orientaron de forma decidida a los infantes como destinatarios principales, quienes emergieron con fuerza en esta década como sujetos consumidores. En efecto, en la década del 30 se consumó una mutación fundamental en los productos dulces que se afianzaron como golosinas, productos específicos para los niños. Por su sabor dulce e "irresistible", los productores y publicistas de dulces lograron ligarlos a ciertos rasgos atribuidos a la infancia, tales como la glotonería, la tentación, o el gusto por el juego, el disfrute y la diversión, y a una novedosa obligación paterna de garantizar la felicidad de los infantes. Este proceso fue también el de la gradual construcción de los niños como sujetos de consumo con cierta autonomía y capacidad para decidir e influir en los presupuestos familiares, que las publicidades buscaban guiar y tutelar, enseñando también a los padres y fundamentalmente a las madres qué productos debían adquirir para sus hijos en orden de garantizar su felicidad y bienestar.

Pero también, de forma novedosa, las publicidades comenzaron a hablar directamente a niños y niñas, apelando a sus gustos y deseos. La finalidad educativa, pedagógica y moralizante que podía advertirse en décadas previas dio paso al entretenimiento, la recreación y la diversión como ejes de los anuncios. Los anuncios apelaron a los gustos infantiles, como parte de una cultura infantil y juvenil barrial ligada a consumos y prácticas como el cine, la literatura de aventuras o el fútbol, que entretenían, divertían y hacían felices a los niños. Esto se ligó a la reciente obligación paterna de proveerles felicidad. Acompañando esta transformación, los adultos fueron invisibilizados en los anuncios, dando paso a un "mundo de niños" donde, si aparecían, era para satisfacer el deseo infantil.

En este proceso, emergieron prácticas publicitarias nuevas. Los concursos, crucigramas, álbumes de figuritas coleccionables y sorteos fueron algunos de los medios empleados que se hicieron dominantes en esta década, afianzándose así la construcción del consumidor infantil, y replicando y masificando parámetros 
y estereotipos de lo que debía ser la infancia, concebida ahora de forma universal. Simultáneamente, la emergencia de un destino único común para toda la infancia en las publicidades puede ser leída como parte de una estrategia de ampliación del mercado identificada como la "parábola de la democratización de los bienes", cuya contracara era la exclusión de aquellos para quienes este consumo era inaccesible, o bien para quienes caían por fuera de la representación de la infancia "apropiada" y universal.

En ese sentido, los anuncios y sus efectos en el mercado fueron una parte importante de procesos de transformación más amplios, tales como la universalización de ciertos valores, espacios y prácticas aplicables ahora a la infancia en su conjunto, junto a políticas de asistencia social que buscaban erosionar la existencia de áreas escindidas entre niños y menores. Cada vez más, niños y niñas fueron concebidos como seres que requerían espacios, diversiones, consumos y cuidados diferentes a los adultos, y los anuncios tuvieron un papel en su difusión. En ese sentido, fueron parte de un proceso más amplio de entronización y valorización de la infancia. En el seno de los hogares, los niños aparecían gradualmente como agentes de consumo con gustos, deseos y cierta autonomía, capaces de influir en el gasto familiar. De esta forma solapada, las publicidades explotaron en su favor la oposición estructural y generacional entre adultez e infancia, signada por la asimetría y la dependencia económica de los niños respecto de los adultos, buscando orientar las demandas de niños y niñas a sus padres en una dirección mercantil económicamente útil a los intereses de las empresas, y de educar a su vez a los padres en la crianza mediante la provisión de bienes. La publicidad fue una de las formas en las que se educó a los pequeños para consumir en el mercado, y una manifestación moderna del valor económico de la infancia.

\section{REFERENCIAS}

Adamovsky, E. (2015). Historia de la clase media argentina: apogeo y decadencia de una ilusión, 1919-2003. Buenos Aires: Booket.

Aguilar, P. L. (2014). El hogar como problema y como solución: una mirada genealógica de la domesticidad a través de las politicas sociales: Argentina 1890-1940. Buenos Aires: CCC.

Arcondo, A. B. (2002). Historia de la alimentación en Argentina: desde los origenes hasta 1920. Córdoba: Ferreyra.

Aristizábal García, D. M. (2016). Niños deseantes y mercados emergentes. Reflexión histórica sobre la infancia y el consumo en Colombia, primera mitad del siglo XX. Trashumante. Revista Americana de Historia Social, 0(8), 200-225. doi:10.17533/udea.trahs.n8a10

Aversa, M. M. (2006). Infancia abandonada y delincuente. De la tutela provisoria al patronato público (1910-1931). En D. Lvovich y J. Suriano (Eds.), Las politicas sociales en perspectiva histórica 1870-1952. Buenos Aires: Prometeo.

Barrancos, D. (1987). Los niños proselitistas de las vanguardias obreras. Buenos Aires: Centro de Estudios e Investigaciones Laborales.

Berger, J. (2000). Modos de ver. Barcelona: Gustavo Gili.

Bontempo, P. (2012). Los niños de Billiken: las infancias en Buenos Aires en las primeras décadas de siglo XX. Anuario del Centro de Estudios Históricos «Prof. Carlos S. A. Segreti», 12(12), 205-221.

Bontempo, P. (2015). Enseñando a las niñas a consumir. La revista infantil Marilú (1933-1937). Avances del Cesor, $12(13), 107-132$.

Bontempo, P. (2016). Los lectores y las lectoras de Billiken se asocian. El desarrollo de los Comités Billiken. Argentina, 1919-1925. Trashumante. Revista Americana de Historia Social, (8), 32-57.

Burke, P. (2005). Visto y no visto: el uso de la imagen como documento histórico. Barcelona: Crítica.

Caldo, P. (2013). Recetas, ecónomas, marcas y publicidades: la educación de las mujeres cocineras de la sociedad de consumo (Argentina, 1920-1945). Arenal. Revista de historia de las mujeres, 20(1), 159-190.

Carli, S. (2005). Los únicos privilegiados son los niños. Todo es historia, 38(457)

Carli, S. (Ed.). (2006). La cuestión de la infancia: entre la escuela, la calle y el shopping. Buenos Aires: Paidós. 
Ciafardo, E. (1992). Los niños en la ciudad de Buenos Aires (1890-1910). Buenos Aires: CEAL

Cosse, I. (2005). La infancia en los años treinta. Todo es historia, 457, 48-57.

Cosse, I. (2006). Estigmas de nacimiento: peronismo y orden familiar, 1946-1955. Buenos Aires: Universidad San Andrés\#: FCE.

Cosse, I., Llobet, V., Villalta, C., y Zapiola, M. C. (2011). Infancias: politicas y saberes en la Argentina y Brasil\#: siglos XIX y XX. Buenos Aires: Agencia Nacional de Promoción Científica y Tecnológica\#: CONICET\#: Universidad Nacional de General Sarmiento\#: Teseo\#: Fundación Centro de Estudos Brasileiros\#: Universidad Nacional de San Martín.

Cuesta, E. M., y Vence Conti, A. (2014). Políticas laborales y salarios durante el primer radicalismo y el primer peronismo (1916-1955). Revista de economia política e história econômica, 32, 274-300.

Dussaillant Christie, J. (2016). La publicidad para la salud infantil en la prensa chilena (1860-1920). Cuadernos de Historia, (45), 89-115.

Elena, E. (2011). Dignifying Argentina: Peronism, citizenship, and mass consumption. Pittsburgh: University of Pittsburgh Press.

Gerchunoff, P., y Aguirre, H. (2006). La economía argentina entre la gran guerra y la gran depresión. United Nations Publications, CEPAL.

Gilbert, C. L. (2016). The Dynamics of the World Cocoa Price. En M. P. Squicciarini y J. Swinnen (Eds.), The Economics of Chocolate (pp 307-338). Oxford: Oxford University Press.

Guy, D. J. (1998). The Pan American Child Congresses, 1916-1942: Pan Americanism, Child Reform, and the Welfare State in Latin America. Journal of Family History, 23:3, 171-191.

Hora, R., y Losada, L. A. (2011). Clases altas y medias en la argentina, 1880-1930. Notas para una agenda de investigación. Desarrollo Económico, 50(200), 611-630.

de Lauretis, T. (1996). La tecnología del género. Mora. Revista del Instituto Interdisciplinario de Estudios de Género, 2, 6-34.

Lionetti, L., y Míguez, D. (2010). Las infancias en la historia argentina: intersecciones entre prácticas, discursos e instituciones, 1890-1960. Rosario: Prohistoria.

Llobet, V. (Ed.). (2014). Pensar la infancia desde América Latina: un estado de la cuestión. Buenos Aires: CLACSO.

Mangone, C. (1989). La república radical: entre Crítica y El Mundo. Yrigoyen entre Borges y Arlt (1916-1930). Historia social de la literatura argentina (pp 73-103). Buenos Aires: Contrapunto.

Marchand, R. (1985). Advertising the American Dream: Making Way for Modernity, 1920-1940. University of California Press.

Míguez, E. J. (1999). Familias de clase media: la formación de un modelo. En F. Devoto y M. Madero (Eds.), Historia de la vida privada en la Argentina (pp 21-46). Buenos Aires: Taurus.

Milanesio, N. (2014). Cuando los trabajadores salieron de compras: nuevos consumidores, publicidad y cambio cultural durante el primer peronismo. Buenos Aires: Siglo Veintiuno.

Minzi, V. (2006). Los chicos según la publicidad. Representaciones de infancia en el discurso del mercado de productos para niños. La cuestión de la infancia. Entre la escuela, la calle y el shopping (pp 209-240). Buenos Aires: Paidós.

Nari, M. M. A. (2004). Politicas de maternidad y maternalismo politico: Buenos Aires, 1890-1940. Buenos Aires: Biblos.

Pérez, I. (2015). Apuntes para el estudio del consumo en clave histórica. Avances del Cesor, 12(13), 97-106.

Pite, R. E. (2013). Creating a Common Table in 20th-century Argentina. Chapell Hill: UNC Press Books.

Pollock, G. (1990). Missing women: rethinking early thoughts on images of women. The critical image: Essays on contemporary photography (pp 202-219). Seattle: Bay Press.

Pope, D. (2003). Making sense of advertisements. Recuperado mayo 1, 2017, a partir de http://historymatters.gmu.e $\mathrm{du} / \mathrm{mse} / \mathrm{ads} / \mathrm{ads} . \mathrm{pdf}$ 
Queirolo, G. A. (2014). Saberes profesionales, movilidad ocupacional e inequidad laboral: el trabajo femenino en el sector administrativo (Buenos Aires, 1910-1950) (Tesis de Doctorado en Historia). Buenos Aires: Facultad de Filosofía y Letras, Universidad de Buenos Aires.

Ramos, J. (1989). Desencuentros de la modernidad en América Latina: literatura y política en el siglo XIX. México: FCE.

Remedi, F. J. (2006). Dime qué comes y cómo lo comes y te diré quién eres: una historia social del consumo alimentario en la modernización argentina. Córdoba, 1870-1918. Córdoba: Centro de Estudios Históricos «Prof. Carlos S.A. Segreti».

Ríos, J. C., y Talak, A. M. (2002). La niñez en los espacios urbanos (1890-1920). En F. Devoto y M. Madero (Eds.), Historia de la vida privada en la Argentina. Tomo II. La Argentina plural. 1870-1930 (pp 138-161). Buenos Aires: Taurus.

Rocchi, F. (1998). Consumir es un placer: La industria y la expansión de la demanda en Buenos Aires a la vuelta del siglo pasado. Desarrollo Económico, 37(148), 533-558.

Rocchi, F. (1999). Inventando la soberanía del consumidor: publicidad, privacidad y revolución del mercado en Argentina, 1860-1940. En F. Devoto y M. Madero (Eds.), Historia de la vida privada en la Argentina (pp 300-321). Buenos Aires: Taurus.

Rocchi, F. (2003). La americanización del consumo. Las batallas por el mercado argentino. En M. I. Barbero y A. Regalsky (Eds.), Americanización: Estados Unidos y América Latina en el siglo XX (pp 131-190). Caseros: UNTREF.

Rocchi, F. (2006). Chimneys in the desert. Industrialization in Argentina during the export boom years, 1870-1930. Stanford: Stanford University Press.

Rocchi, F. (2016). A la vanguardia de la modernización: la incipiente formación de un campo publicitario en la Argentina durante la década de 1920. Estudios Interdisciplinarios de América Latina y el Caribe, 27(2). Recuperado a partir de http://eial.tau.ac.il/index.php/eial/article/view/1439

Rocchi, F. (2017). La sociedad de consumo en tiempos difíciles: el modelo estadounidense y la modernización de la publicidad argentina frente a la crisis de 1930. Historia Crítica, (65), 93-114. doi:10.7440/histcrit65.2017.05

Rogers, G. (2008). Caras y Caretas: cultura, politica y espectáculo en los inicios del siglo XX argentino. Buenos Aires: EdULP.

Rojas Flores, J. (2005). Juegos y alegrías infantiles. Historia de la vida privada en Chile, vol. 2 (pp 349-388). Santiago de Chile: Taurus.

Romano, E. (2004). Revolución en la lectura: el discurso periodístico-literario de las primeras revistas ilustradas rioplatenses. Buenos Aires: Catálogos\#: El Calafate.

Saítta, S. (2000). El periodismo popular en los años veinte. Nueva Historia Argentina. Democracia, conflicto social y renovación de ideas (1916-1930) (pp 435-471). Buenos Aires: Sudamericana.

Salvatore, R. D. (2005). Yankee Advertising in Buenos Aires. Interventions, 7(2), 216-235. doi:10.1080/13698010500146773

Scheinkman, L. (2017a). Trabajo femenino, masculino e infantil en la industria del dulce porteña en la primera mitad del siglo XX: experiencias laborales, protesta y vida cotidiana (Tesis de Doctorado en Historia). Buenos Aires: Facultad de Filosofía y Letras, Universidad de Buenos Aires.

Scheinkman, L. (2017b). Dulces consumidores. La construcción publicitaria del consumo femenino e infantil de golosinas en las primeras décadas del siglo XX en la Argentina. Meridional. Revista Chilena de Estudios Latinoamericanos, 0(9), 145-190.

Sosenski, S. (2012). El niño consumidor: una construcción publicitaria de mediados de siglo XX. En A. Acevedo y P. López Caballero (Eds.), Ciudadanos inesperados. Procesos de formación de la ciudadania ayer y hoy (pp 191-222). México: El Colegio de México/CINVESTAV, Departamento de Investigaciones Educativas.

Sosenski, S. (2014). Educación económica para la infancia: el ahorro escolar en México (1925-1945). Historia Mexicana, 64(2), 645-711. 
Sosenski, S., y León, R. L. (2015). La construcción visual de la felicidad y la convivencia familiar en México: los anuncios publicitarios en la prensa gráfica (1930-1970). Secuencia, (92), 194-225.

Salvatore, R. D. (2005). Yankee Advertising in Buenos Aires. Interventions, 7(2), 216-235. doi:10.1080/13698010500146773

Szir, S. (2007). Infancia y cultura visual: los periódicos ilustrados para niños (1880-1910). Buenos Aires: Miño y Dávila.

Szir, S. (2009). Entre el arte y la cultura masiva. Las ilustraciones de la ficción literaria en Caras y Caretas (1898-1908). En L. Malosetti Costa y M. M. Gené (Eds.), Impresiones porteñas. Imagen y palabra en la historia cultural de Buenos Aires (pp 109-139). Buenos Aires: Edhasa.

Szir, S. (2013). Imágenes para la infancia. Entre el discurso pedagógico y la cultura del consumo en Argentina. La escuela y el periódico Ilustrado Caras y Caretas (1880-1910). En S. Sosenski y E. Jackson Albarrán (Eds.), Nuevas miradas a la historia de la infancia en América Latina: entre prácticas y representaciones (pp 123-152). México.

Torre, J. C., y Pastoriza, E. (2002). La democratización del bienestar en los años peronistas. Nueva Historia Argentina. Los años peronistas (Vol. 8, pp 257-313).

Traversa, O. (1997). Cuerpos de papel. Figuraciones del cuerpo en la prensa 1918-1940. Barcelona: Gedisa.

Vezzetti, H. (1986). Viva cien años: algunas consideraciones sobre familia y matrimonio en la Argentina. Punto de Vista, 27, 5-10.

Villalta, C. (2010). Infancia, justicia y derechos humanos. Bernal: Universidad Nacional de Quilmes.

Zapiola, M. C. (2009). Los niños entre la escuela, el taller y la calle. Buenos Aires, 1884-1915. Cadernos de Pesquisa, 39(136), 69-81.

Zelizer, V. A. (1994). Pricing the Priceless Child: The Changing Social Value of Children. Princeton University Press

\section{DOCUMENTACIÓN PRIMARIA IMPRESA:}

Album con los personajes de Walt Disney. Kelito. Buenos Aires, Noel y Cía., 1941.

Álbum de figuritas Series A y C. Buenos Aires: Águila Saint Hnos., 1938.

Álbum de figuritas. Montevideo: Águila Saint Hnos., 1932.

Álbum de figuritas. Montevideo: Águila Saint Hnos., 1937

Álbum Kelito (clubes de fútbol). Buenos Aires, Noel y Cía., 1932.

Álbum Kelito Noel. Aventuras Maravillosas. Tomo I. Buenos Aires, Noel y Cía., 1934

Asociación Fabricantes de Dulces, Conservas y Afines: álbum aniversario. Buenos Aires: Asociación Fabricantes de Dulces, Conservas y Afines, 1937.

Catálogo general del año 1935. Buenos Aires: Águila Saint Hnos., 1935.

Chocolatines Águila. Álbum Nº . Buenos Aires: Águila Saint Hnos., s.f. (ca. 192 ).

Envoltorio de chocolate Kelito. Buenos Aires, Noel y Cía., 1933, 1936.

Figurita de futbol (Quilmes), Álbum Kelito. Buenos Aires, Noel y Cía., 1933.

Figuritas de fútbol. Buenos Aires: Águila Saint Hnos., 1926.

Gil Blas De Santillana. Buenos Aires: Águila Saint Hnos., s.f. (ca. 1935)

La Vida De Lazarillo De Tormes. Buenos Aires: Águila Saint Hnos., s.f. (ca. 1935).

La vida de los animales. Buenos Aires: Águila Saint Hnos., 1935.

Las Aventuras De Pirucho. Buenos Aires: Águila Saint Hnos., s.f. (ca. 1935).

Precios corrientes. Buenos Aires: Noel y Cía. Sociedad Argentina de Dulces y Conservas. 9/1936.

\section{Publicaciones Periódicas:}

Caras y Caretas, 1898-1939. 
Colibrí, 1921-1932.

El Mundo, 1931, 1933, 1934, 1936, 1940, 1942, 1944, 1945.

Boletin Informativo del Departamento Nacional del Trabajo, 1936

La Vanguardia, 1924, 1933, 1934.

Leoplan, 1943.

\section{Grupos de FACEBOOK:}

Facebook Infinita Buenos Ayres [accedido 24/5/2016]: https://www.facebook.com/Infinita-Buenos-Ayres-131550 $064017 /$ ? fref $=$ ts

\section{Notas}

1 Alejandra Liniado, comentario en Facebook Infinita Buenos Ayres, 24/5/2016 [accedido 24/5/2016], en: https://www.facebook.com/permalink.php?story_fbid=10154826386969018\&id=131550064017\&comment_i $\mathrm{d}=10154826873944018 \neg$ if_t $=$ comment_mention $\neg$ if_id $=1464028572198526$

2 Es preciso notar que esta definición de la felicidad infantil ligada a los intereses de la industria no fue excluyente y convivió con otras que consideraban por ejemplo que la felicidad de los niños y niñas era resultado de la unión familiar, de la bondad, el amor y los cuidados maternos, entre otras (Stearns, 2010). Por otro lado, y teniendo en cuenta que el tópico de la felicidad en la publicidad no es exclusivo de la industria alimenticia ni de los productos dirigidos a la infancia, sino que se encuentra entre el repertorio de ideas que utiliza el marketing, esta definición de felicidad infantil se distanciaba de otras "felicidades", tales como la felicidad femenina o conyuga" (Traversa, 1997).

3 Stearns puntualiza además otros tres grandes cambios con los que se relaciona la difusión del ideal de la felicidad infantil: la emergencia de nuevos saberes y expertos en crianza, el descenso de la tasa de mortalidad infantil, y la difusión de la "alegría" (cheerfulness) como objetivo y sinónimo del éxito en la vida adulta (Stearns, 2010, pp 175-177).

4 La búsqueda en $\mathrm{CyC}$ fue posible gracias al repositorio digital de la Hemeroteca de la Biblioteca Nacional de España: http://hemerotecadigital.bne.es/index.vm. Todas las reproducciones de imágenes de CyC proceden de la Biblioteca Nacional de España. Las reproducciones de El Mundo provienen de la Biblioteca Nacional de la República Argentina, así como varios libros y álbumes, mientras que otros son parte de la colección personal de la autora.

5 Como señala Fernando Rocchi este mercado era fundamentalmente urbano, y Ricardo Salvatore ha puntualizado que de hecho excluía a las regiones y consumidores más pobres del país, aunque productos de consumo relativamente baratos como los dulces eran más inclusivos (Rocchi, 2016, p 51; Salvatore, 2005, pp 227-228).

6 Otros trabajos parten del piso de 1918, respecto del cual el salario real aumentó un 50\% durante el período radical (Gerchunoff y Aguirre, 2006)

7 Jacobo Ivitz, "Debe procurarse el perfeccionamiento en la elaboración de dulces y conservas", Asociación fabricantes de dulces, conservas y afines: álbum aniversario, 39.

8 Curt Uhlitzsch, “¿Porque se regala el cacao en polvo en la argentina?”, Asociación fabricantes de dulces, conservas y afines: álbum aniversario, 45.

9 Este término, que se hizo usual en la época, expresaba los temores en torno al decrecimiento de la población y la decadencia de sus características (Cosse, 2005, p 49; Nari, 2004, pp 28-30)

10 Esta separación del mundo infantil respecto del adulto fue impulsada desde principios de siglo por el anarquismo y el socialismo (Barrancos, 1987).

11 Fue mensual de 1921 a 1923, y quincenal de 1924 a 1932 (sobre Colibrí, Bontempo, 2012).

12 Chocolatines Águila. Álbum Nº1. Buenos Aires: Águila Saint Hnos., s.f. (ca. 192 ).

13 Como antecedentes debemos mencionar también Las ocurrencias de Carlitos, pequeño librito sobre Charles Chaplin que Bagley remitía a sus consumidores a cambio de cupones (ver anuncios en CyC durante 1917 y 1918); y El cine. Periódico Infantil Cinematográfico, semanario con reportajes, retratos de estrellas, cuentos, crónicas y novedades sobre cine, que Noel publicaba y distribuía "para recreo de los pequeños consumidores de las golosinas", y enviaba gratis a cambio de un cupón. CyC, 4/10/1924; no se han conservado ejemplares.

14 Por ejemplo, una publicidad de Godet de 1936 mostraba un álbum de figuritas, con la indicación: “Así deben pegarse las calcomanías", enseñando e indicando cómo debía utilizarse el producto. CyC, 10/10/1936. 
15 Paula Bontempo ha advertido también en la publicación infantil Billiken el éxito de la tira sobre las andanzas de Comeuñas y la barra de la esquina fundadora del Sacachispas Football Club, publicada entre 1931 y 1935, centrada en las aventuras de una banda de niños de entre 10 y 13 años, en torno al fútbol y el barrio (Bontempo, 2012, pp 218-220)

16 Este introdujo modificaciones tanto en las políticas de la infancia como en sus juegos, consumos y características (Torre y Pastoriza, 2002; Elena, 2011; Milanesio, 2014; sobre la infancia durante el peronismo: Carli, 2005; Cosse, 2006)

17 CyC, 9/7/1938, 59. En 1936 un kilo de pan costaba 28 centavos. "Costo de la vida", Boletín Informativo del Departamento Nacional del Trabajo, 5-6/1936, 4607. El salario mensual de una niña obrera en las fábricas de dulces en 1933 era de $\$ 17,5$, mientras que un niño obrero podía llegar a ganar \$62,5. “El conflicto en la casa Groisman”, La Vanguardia, 27/4/1933, 4 (Scheinkman, 2017a, pp 232-241).

18 En cambio en 1934 la temática elegida en el álbum "Aventuras maravillosas", fueron los extractos de novelas de Julio Verne como Miguel Strogoff; y en 1941, fueron los personajes de la compañía norteamericana de animación para niños Walt Disney.

19 Por ejemplo: CyC, 22/8/1931; CyC, 23/9/1931; CyC, 28/3/1936; El Mundo,14/10/1936.

20 Otra ilustración, también a color, mostraba una niña blanca de mejillas rosadas en un bonito interior hogareño, lamiendo la cuchara con la que había comido dulce mientras un perro vigilaba atento. CyC, 5/9/1931.

21 CyC, 4/6/1932

22 Por ejemplo un anuncio de Noel publicitaba a la "Señora Ortiz de Sáenz", ecónoma, que enseñaba recetas de pastelería. СyC, 27/7/1929, 173. En los años '50 y '60 las marcas comenzaron a distribuir recetarios gratuitamente a sus consumidoras (como el Recetario de cocina del chocolate Águila, s.f. (ca. 1950-1960), o A su desayuno... dele sabor de fiesta con chocolate Águila, (1950-1960)).

23 Sobre la expansión del trabajo femenino en el área de servicios en entreguerras, ver Queirolo (2014). 